\title{
Invertebrate diversity in the deep Great Australian Bight (200-5000 m)
}

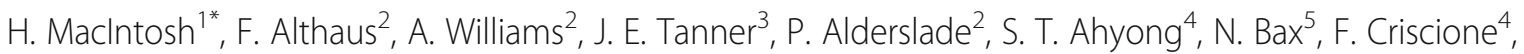 \\ A. L. Crowther ${ }^{6}$, C. A. Farrelly 1 , J. K. Finn', L. Goudie', K. Gowlett-Holmes², A. M. Hosie', E. Kupriyanova ${ }^{4}$, C. Mah $^{8}$, \\ A. W. McCallum', K. L. Merrin ${ }^{1}$, A. Miskelly ${ }^{9}$, M. L. Mitchell', T. Molodtsova ${ }^{10}$, A. Murray ${ }^{4}$, T. D. O'Hara', \\ P. M. O'Loughlin ${ }^{1}$, H. Paxton ${ }^{4}$, A. L. Reid ${ }^{4}$, S. J. Sorokin ${ }^{3}$, D. Staples ${ }^{1}$, G. Walker-Smith', E. Whitfield' and R. S. Wilson ${ }^{1}$
}

\begin{abstract}
Background: The Great Australian Bight (GAB) comprises the majority of Australia's southern coastline, but to date its deep water fauna has remained almost unknown. Recent issuing of oil and gas leases in the region has highlighted this lack of baseline biological data and established a pressing need to characterise benthic abyssal fauna.

Methods: From 2013 to 2017, six large-scale systematic surveys of the GAB were conducted from 200 to $5000 \mathrm{~m}$ depth, constituting the deepest systematic biological sampling in Australia. Sampling was conducted on soft sediment and hard substrates, both at pre-determined depth intervals along north-south transect lines and at sites of interest identified by multibeam sonar.
\end{abstract}

Results: A total of 66,721 invertebrate specimens were collected, comprising 1267 species, with 401 species (32\%) new to science. In addition to the novelty of the fauna, there was a high degree of rarity, with $31 \%$ of species known only from single specimens.

Conclusions: In this paper, we provide an annotated checklist of the benthic invertebrate fauna of the deep GAB, supplemented with colour photos of live specimens and commentary on taxonomy, diversity and distributions. This work represents an important addition to knowledge of Australia's deep sea fauna, and will provide the foundation for further ecological, biogeographical and systematic research.

Keywords: Deep sea, Infauna, Epifauna, Taxonomy, Biodiversity, Biogeography, Great Australian bight

\section{Background}

It is often noted how vast and unexplored the deep sea is, but it is a rare opportunity to explore an almost completely unknown marine region - particularly adjacent to a region famed for its unique biodiversity. Such is the case with the Great Australian Bight (GAB), an area encompassing most of southern Australia's coastline. While deep sea exploration in Australian waters dates back to the Challenger expedition and has included surveys of the Coral Sea (Ahyong, 2012), Norfolk Ridge (Williams et al., 2011), Tasmanian seamounts (Koslow et al., 2001) and Western Australia (McEnnulty et al., 2011), the GAB has been virtually unsampled below continental shelf depths (200 m) (Currie \& Sorokin, 2011;

\footnotetext{
* Correspondence: hmacintosh@museum.vic.gov.au

${ }^{1}$ Museums Victoria, Melbourne, Australia

Full list of author information is available at the end of the article
}

Conlan et al., 2015). Faunal records that exist were mostly collected either on an ad hoc basis from commercial fishing trawls, as part of fisheries bycatch surveys focussing on fishes and with no systematic collection of invertebrates, or from a very small number of opportunistic samples taken from a research vessel passing through the area. These records are also overwhelmingly from the shallower $(<1000 \mathrm{~m})$ part of the depth range sampled during our study (200-4961 m). The recent uptake of deep sea oil and gas leases in the region has highlighted a lack of baseline biological and environmental data, and established a pressing need to characterise the composition, abundance and distributions of benthic fauna before industry activity commences. Two major science programs have been implemented to enhance ecological knowledge of the deep GAB: the GAB Research Program (GABRP) (The 
Great Australian Bight Research Program, 2017), and the GAB Deepwater Marine Program (GABDMP) (The Great Australian Bight Deepwater Marine Program, 2017). These programs have supported six surveys between 2013 and 2017 that targeted the benthic diversity of the deep $G A B$, resulting in a substantial and high-quality collection of epifauna (animals dwelling at or slightly above the surface of the seabed), infauna (animals dwelling within sediment) and bentho-pelagic fauna (suprabenthic). This sampling, and resulting data set, comprise the deepest systematic biological sampling in Australian waters. This paper provides a detailed checklist of the benthic invertebrate fauna of the deep $\mathrm{GAB}$, with colour photos of live specimens and commentary on taxonomy, diversity and distributions. This research is intended to underpin further studies analysing community structure, macroevolution and biogeographic patterns (Williams et al., 2018a; Tanner et al., 2018). Corresponding treatment of the fishes of the deep GAB has also been completed (Williams et al., 2018b). All specimens are now stored in Australian museums and other research institutes where they are accessible to researchers conducting taxonomic, and other studies, ensuring this benthic data set will continue to contribute to knowledge and understanding of the deep sea fauna in local, regional and global contexts.

\section{Methods}

\section{Biological sampling}

The geomorphology of the GAB is broadly similar to most continental margins, with a moderately wide continental shelf (0-200 m depth), continental slope and rise (200$5000 \mathrm{~m}$ depth) and large abyssal plain $(>5000 \mathrm{~m})$. The Ceduna sub-basin, where most sampling took place, features a notably wide, gently descending slope (Sayers et al., 2003). The majority of the deep GAB consists of soft substrates comprised primarily of thick pelagic ooze (Rogers et al., 2013). In contrast with this soft, homogenous environment are several volcanic seamounts associated with the Bight Basin Igneous Complex (BBIC), consisting of heterogeneous, basaltic rock substrates (Williams et al., 2018c). The continental slope also bears a series of incised canyons and outcroppings, exposing sedimentary layers of the Ceduna sub-basin (Williams et al., 2018c). As deep sea communities can vary greatly with both depth and substrate type (Rowden et al., 2016), sampling was designed to cover a full range of bathomes as well as substrates to ensure a representative collection of fauna could be made.

Benthic invertebrates were collected on six offshore surveys (Table 1) by the RV Southern Surveyor (voyage SS2013_C02), RV Southern Supporter (survey FU201301), RV Investigator (surveys IN2015_C01, IN2015_C02 and IN2017_C01) and Industry Inspection Vessel REM Etive (RE2017_C01) (MNF, 2013; MNF, 2015a; MNF, 2015b). Surveys SS2013_C02 and IN2015_C02 sampled stations along five transects, at depths of 200, 400, 1000, 1500, 2000 and 2800 m (30 sites; Fig. 1). Survey FU201301 opportunistically collected biological samples at seven sites identified as being of particular interest for the drilling of exploration wells. The IN2015_C01 and IN2017_C01 surveys were focussed on targets of interest at 1000 to $5000 \mathrm{~m}$ depth, including rocky outcroppings in canyons, volcanic seamounts, and potential seep zones (21 sites; Fig. 1). Survey RE2017_C01 used two sub-sea Remotely Operated Vehicles (ROVs) to closely explore five of these sites.

Biological sampling totalled 304 operations over 58 sites, using eight gear types (Table 2, Fig. 1). This mix of site selection and sampling gear ensured that a wide range of habitat types and their associated fauna were sampled.

Epifauna mainly consisting of animals larger than $10 \mathrm{~mm}$ in size, and living on or just below the sediment surface, were predominantly collected using three gear types suited to different terrains. The main sampling tool was a beam trawl with a mouth size of $4.0 \mathrm{~m}$ wide $\times$ $0.5 \mathrm{~m}$ high fitted with a net bag that has a $25 \mathrm{~mm}$ stretch mesh cod end, designed at CSIRO (Lewis, 2010) but adapted from another design (Forest, 1981). This gear was used for sampling flat, soft sediment terrains, where it recovered nearly 70,000 specimens of invertebrates in 63 operations. Harder and rougher substrates, such as seamounts and rocky outcrops were sampled using the 'Sherman sled', a CSIRO designed and built robust epibenthic sampler with a mouth-size of $1.2 \mathrm{~m}$ wide

Table 1 Summary of deep water surveys in the Great Australian Bight, 2013-2017, with survey duration and number of sampling operations

\begin{tabular}{lllll}
\hline Survey Name & Vessel & Dates & Depth Range & Operations \\
\hline SS2013_C02 & RV Southern Surveyor & $03.04 .2013-22.04 .2013$ & $189-2018 \mathrm{~m}$ & 32 \\
FU201301 & RV Southern Supporter & $09.04 .2013-08.05 .2013$ & $478-2095 \mathrm{~m}$ & 5 \\
IN2015_C01 & RV Investigator & $25.10 .2015-25.11 .2015$ & $932-4677 \mathrm{~m}$ & 66 \\
IN2015_C02 & RV Investigator & $29.11 .2015-22.12 .2015$ & $184-3021 \mathrm{~m}$ & 48 \\
RE2017_C01 & REM Etive & $10.03 .2017-06.04 .2017$ & $1338-3079 \mathrm{~m}$ & 133 \\
IN2017_C01 & RV Investigator & $10.04 .2017-28.04 .2017$ & $137-4961 \mathrm{~m}$ & 20 \\
\hline
\end{tabular}




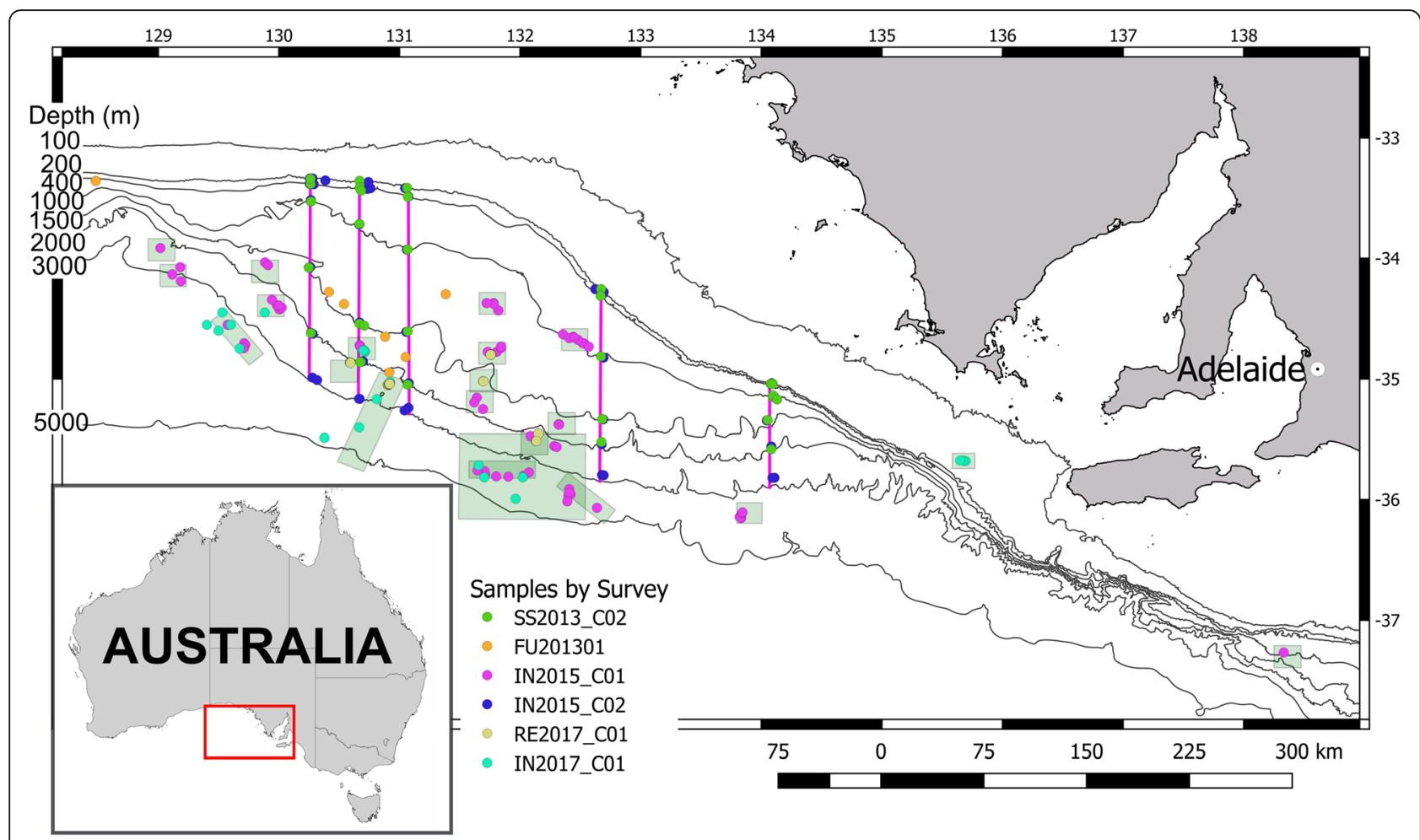

Fig. 1 Map of the central and eastern GAB regions showing the sampling stations from each of the six GAB deep water surveys (marked as coloured circles). The sampling transects (pink lines) and target sites (green shaded) are shown

$\times 0.6 \mathrm{~m}$ high, fitted with a $25 \mathrm{~mm}$ stretch mesh cod end (Lewis, 1999; Lewis, 2009), and a standard Geoscience Australia design rock dredge. The latter is constructed from heavy steel, has a mouth-size of $0.90 \mathrm{~m}$ wide $\times$ $0.35 \mathrm{~m}$ high and fitted with a $1.0 \mathrm{~m}$ long chain mesh bag that has $50 \mathrm{~mm}$ gaps; dragging behind the main dredge were two parallel pipe dredges made from $0.2 \mathrm{~m}$ diameter $\times 0.6 \mathrm{~m}$ long pieces of heavy steel fitted at the end with expanded metal mesh. All epifauna were sorted on board immediately after retrieval of samples and given provisional identifications by a team of taxonomists.
In addition to the epifauna collections, 75 operations were conducted to collect soft sediment macro-infauna, using corers and grabs. Most samples were taken with a multicorer fitted with six $100 \mathrm{~mm}$ diameter tubes to collect undisturbed sections of sediment (Sherlock et al., 2014); the top $150 \mathrm{~mm}$ and any top water were removed, elutriated onto $300 \mu \mathrm{m}$ sieves and preserved on board, with more detailed sorting and analysis post-survey. The infaunal invertebrates are included here with the epifauna as part of the total abundance and diversity. All specimens, with the exception of Actiniaria (preserved

Table 2 Summary of operations where invertebrate fauna was collected, with total specimens and species collected by each gear type

\begin{tabular}{llll}
\hline Gear type & Total operations & Total specimens $^{\text {a }}$ & Total species $^{b^{b}}$ \\
\hline Beam Trawl & 62 & 85,783 & 907 \\
Rock Dredge & 27 & 1018 & 103 \\
Benthic Sled & 10 & 232 & 57 \\
Instrumented Corer/Multicorer & 51 & 957 & 160 \\
Piston Corer & 8 & 90 & 14 \\
Smith-Macintyre Grab & 13 & 149 & 62 \\
ROV Pushcore & 31 & 581 & 56 \\
ROV collection & 102 & 633 & 143 \\
Total: & 304 & 89,443 & 1459 \\
\hline
\end{tabular}

${ }^{a}$ Total specimens collected, including specimens not included in further totals and analyses, due to damage or lack or taxonomic expertise (e.g. Nematoda)

${ }^{b}$ Total species includes all Operational Taxonomic Units identified. Gear totals show all species collected by that gear type, not species unique to that gear 
in 5\% formalin), were preserved in $95 \%$ ethanol to enable future molecular analyses.

The RE2017_C01 survey was conducted with two FCV 3000, $150 \mathrm{hp}$. sub-sea ROVs, capable of diving to $3000 \mathrm{~m}$, for detailed in situ examination of fauna and geology in seven dive locations at five sites. A variety of mounted sampling tools (chisels, scoops, nets) were used to make targeted collections of biota, and push cores were used to sample sediment fauna. Having the opportunity to carefully select specimens and manipulate them individually into a sampling container at depth, meant successful collection of particularly fragile taxa that were rarely seen intact in the net samples. Specimens were processed according to the same protocols listed above.

Wherever possible, specimens were photographed immediately after collection, with an aim to record natural colour and morphology. These photographs are contained in Additional file 1.

\section{Analysis}

Post survey, the material was distributed to participating institutions for analysis by specialist taxonomists. Taxa were selected for analysis and discussion based on their abundance in the collections and availability of taxonomic expertise. Specimens that were damaged beyond recognition or for which there was no available expertise (e.g. Nematoda) were excluded from analysis (1070 lots in 257 OTUs). Upgrading of the fauna included identification to the lowest possible Operational Taxonomic Unit (OTU), each representing a unique species. Species of uncertain identity were recorded with the prefix '?' or 'cf.'; putative new species were noted as 'n. sp.' or given a unique identifier e.g. 'Notomastus sp. MoV 6840'. For each taxonomic group presented here, a brief review of the group's deep sea biology and ecology was provided. Results for each OTU were placed in a taxonomic and biogeographic context, noting whether they were new to science, previously recorded from Australia, recorded from southern Australia or recorded from the GAB. All specimens are permanently lodged at Australian museums and are available for future examination (Table 3).

Species accumulation (sample order: 999 permutations) were plotted, for each gear and seven depth strata, separately (Fig. 2). Each gear deployment was considered a sample; replicate cores taken during a deployment of the ICP/Multi-corer were combined for this analysis.

Gear type may be considered a proxy for the substrate sampled, with only dredge, sled and ROV used to sample hard substrate terrains. Detailed analysis by substrate or habitat type was considered beyond the scope of this paper and is explored in accompanying publications (Williams et al., 2018a; Williams et al., 2018c).

Sampling on two of the surveys included here was deliberately depth stratified, targeting strata based on generally reported bathymetric patterns in the deep sea (Williams et al., 2018a; Last et al., 2010). Sampling depths of all deployments included here formed clusters around one of the six depth strata targeted by these surveys (200, 400, 1000, 1500, 2000, $3000 \mathrm{~m}$ ), and a seventh stratum, $4000 \mathrm{~m}$. Thus, assigning samples to those strata was based on natural breaks in the data. The depth ranges included in each stratum are: $200(137-283 \mathrm{~m}), 400(358-483 \mathrm{~m}), 1000$ $(932-1263 \mathrm{~m}), \quad 1500 \quad(1321-1863 \mathrm{~m}), 2000 \quad$ (1904$2366 \mathrm{~m}), 3000$ (2467-3465 m), 4000 (> $3530 \mathrm{~m})$.

\section{Results}

The combined biological sampling operations collected a total of 66,721 benthic invertebrate specimens, from 3522 separate lots (with a 'lot' defined as a sample containing one or more individuals of a single taxon). After taxonomic analysis, the material was determined to comprise 1267 species, 710 genera and 386 families, from eleven phyla. Of the total species, at least 401 (32\%) are new to science and many are currently being formally described. The major taxa recovered are summarised in Table 3, with a more detailed listing contained in Additional file 2. More detailed analyses and discussion of each major group follows.

Species accumulation curves (Fig. 2a, Table 4) show most sampling effort concentrated at the $1500 \mathrm{~m}$, $2000 \mathrm{~m}$ and $2500 \mathrm{~m}$ bathomes. While ROVs were used for the most distinct sampling operations (102 operations) (Table 2), each ROV sampling event was a highly selective sampling of a few individuals and accordingly the total number of samples retrieved by ROV was limited (633 specimens). The most specimens and species were retrieved by Beam Trawl operations (907 spp.), followed by Multicorer (160 spp.), ROV grab (143 spp.), and Rock Dredge (103 spp.).

\section{Porifera \\ S.J. Sorokin, L. Goudie}

There are over 8500 valid sponge species worldwide; of these approximately $83 \%$ are in the class Demospongiae, with the remainder distributed amongst the classes Calcarea (8\%), Hexactinellida (8\%) and Homoscleromorpha (1\%) (van Soest et al., 2012). Hexactinellida in particular have predominantly bathyal and abyssal distributions (van Soest et al., 2012), although the other three classes are also found in deep water (van Soest, 2009; Rapp et al., 2011; Domingos et al., 2016). In Australia, the most up-to-date Porifera species list is found at the online register of Codes of Australian Aquatic Biota (CAAB) (Rees et al., 1999). This lists 1710 named sponge species in Australia, approximately $20 \%$ of the worldwide count.

In the combined GAB surveys, 225 taxa were identified. The sponge fauna is poorly described, thus the 
Table 3 Overall taxonomic and abundance summary of invertebrate fauna, by major taxonomic group. 'Lodged at' notes museum collection where voucher material was deposited

\begin{tabular}{|c|c|c|c|c|c|c|c|c|}
\hline Phylum & Major group & Total specimens & Families & Genera & Species & Undescribed species & Lodged at & Note \\
\hline \multirow[t]{3}{*}{ Porifera } & Demospongiae & 10,870 & 36 & 64 & 142 & 3 & SAMA & \\
\hline & Calcarea & 106 & 10 & 16 & 34 & 7 & SAMA & \\
\hline & Hexactinellida & 113 & 7 & 11 & 49 & 5 & SAMA & \\
\hline \multirow[t]{8}{*}{ Cnidaria } & Hydroida $^{a}$ & 55 & - & - & - & - & NMV & \\
\hline & Siphonophorae & 120 & 1 & 1 & 1 & & NMV & \\
\hline & Antipatharia & 16 & 4 & 6 & 9 & 1 & CSIRO & \\
\hline & Octocorallia & 625 & 18 & 42 & 74 & 40 & CSIRO & 3 new genera \\
\hline & Actiniaria & 1109 & 9 & 21 & 56 & 28 & SAMA & \\
\hline & Corallimorpharia & 49 & 1 & 2 & 3 & 0 & SAMA & \\
\hline & Zoantharia $^{a}$ & 180 & - & - & - & - & SAMA & \\
\hline & Scleractinia & 1783 & 5 & 10 & 16 & 5 & SAMA & \\
\hline Brachiopoda & - & 374 & 4 & 4 & 5 & 0 & SAMA & \\
\hline Bryozoa & - & 9 & 4 & 4 & 6 & 0 & SAMA & \\
\hline Nemertea $^{a}$ & - & 13 & - & - & - & - & SAMA & \\
\hline Nematoda $^{a}$ & - & 382 & - & - & - & - & SAMA & \\
\hline \multirow[t]{4}{*}{ Annelida } & Sipuncula & 1037 & - & - & 8 & - & SAMA & \\
\hline & Echiura & 21 & - & - & 1 & - & SAMA & \\
\hline & Polychaeta & 1267 & 40 & 95 & 167 & 104 & SAMA, NMV, AM & \\
\hline & Oligochaeta & 39 & 2 & 2 & 3 & 1 & SAMA & \\
\hline \multirow[t]{6}{*}{ Mollusca } & Aplacophora & 25 & 3 & 3 & 6 & 1 & SAMA & \\
\hline & Polyplacophora & 3 & 1 & 1 & 1 & 0 & SAMA & \\
\hline & Bivalvia & 2103 & 18 & 29 & 43 & 0 & SAMA, NMV & \\
\hline & Scaphopoda & 541 & 4 & 5 & 11 & 4 & AM & \\
\hline & Cephalopoda & 79 & 13 & 15 & 23 & 4 & AM & \\
\hline & Gastropoda & 1468 & 42 & 78 & 110 & 54 & AM, NMV & 2 new genera \\
\hline \multirow[t]{5}{*}{ Echinodermata } & Crinoidea & 8 & 3 & 4 & 4 & 2 & NMV & \\
\hline & Asteroidea & 1645 & 18 & 40 & 89 & 17 & NMV & \\
\hline & Ophiuroidea & 35,041 & 23 & 33 & 64 & 12 & NMV & \\
\hline & Echinoidea & 932 & 12 & 16 & 19 & 1 & $A M$ & \\
\hline & Holothuroidea & 1707 & 12 & 22 & 32 & 17 & NMV & \\
\hline \multirow[t]{9}{*}{ Arthropoda } & Cirripedia & 678 & 5 & 18 & 32 & 1 & WAM & \\
\hline & Cumacea & 15 & - & - & - & - & SAMA & \\
\hline & Tanaidacea & 95 & - & - & 14 & 0 & SAMA & \\
\hline & Isopoda & 599 & 21 & 45 & 61 & 50 & NMV, SAMA & 4 new genera \\
\hline & Amphipoda & 184 & 27 & 38 & 52 & 19 & NMV, SAMA & \\
\hline & Lophogastrida & 14 & 1 & 1 & 2 & 0 & $A M$ & \\
\hline & Decapoda & 2805 & 36 & 75 & 114 & 20 & AM & \\
\hline & Stomatopoda & 16 & 2 & 2 & 2 & 0 & AM & \\
\hline & Pycnogonida & 142 & 4 & 7 & 14 & 5 & NMV & \\
\hline \multirow[t]{2}{*}{ Chordata } & Ascidiacea $^{a}$ & 453 & - & - & - & - & SAMA & \\
\hline & Total & 66,721 & 386 & 710 & 1267 & 401 & & \\
\hline
\end{tabular}

axa not included in Additional file 2 due to lack of taxonomic expertise 


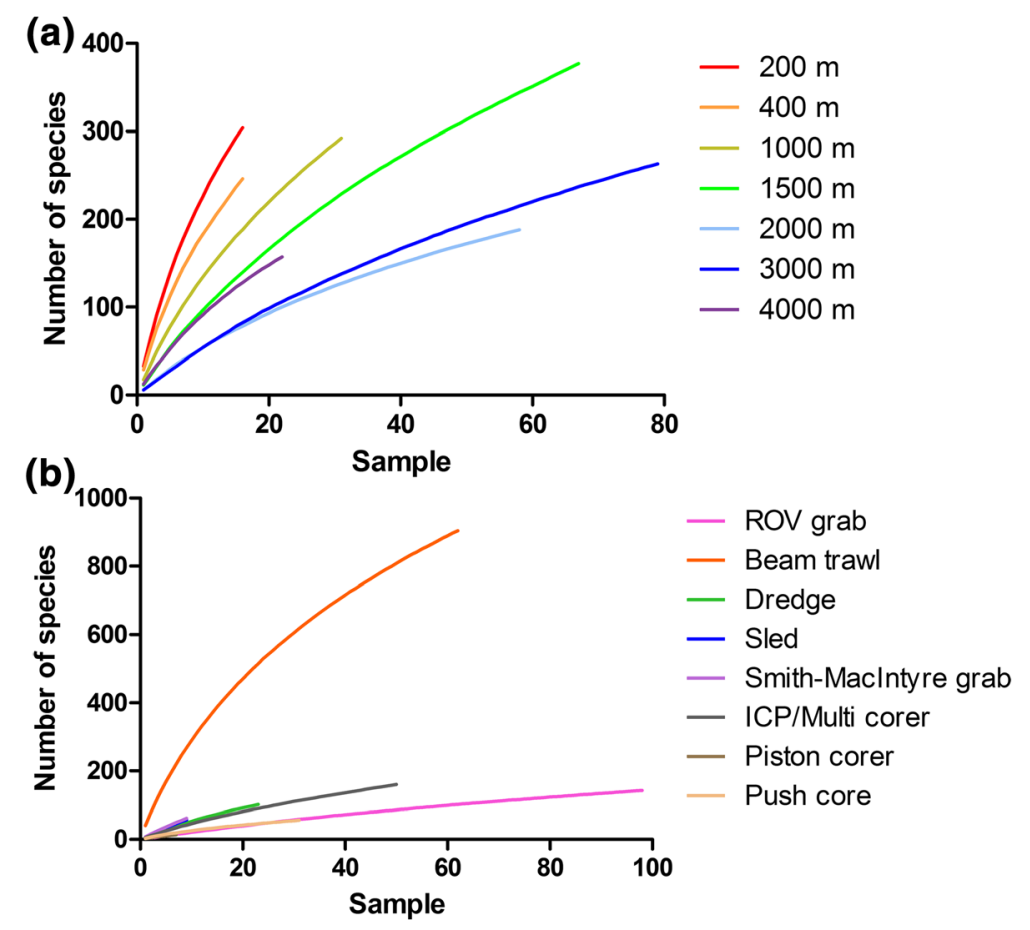

Fig. 2 Species accumulation curves by (a) depth zone and (b) gear type (999 permutations of samples)

majority of the sponges could not be identified to species level. Instead, they were assigned alpha-numeric codes, each of which has a detailed sponge 'mudmap' description (following Hooper et al. (Hooper et al., 2013)) for future reference. In literature on sponges it is also common to cite the number of species at the 'Order' level to compare similar collections. The four most speciose Orders in this collection were Haplosclerida (33), Axinellida (26), Dictyoceratida (24) and Amphidiscosida (21). However, molecular systematics has recently instigated major changes in the classification of Demospongiae (Morrow \& Cárdenas, 2015), making comparisons with previous collections difficult.

Demospongiae (142 taxa) were the most common Class, followed by Calcarea (34) and Hexactinellida (49). Two species dominated the sponge biomass. The haplosclerid fan sponge Callyspongia (Callyspongia) sp. made up $27 \%$ of the total sponge biomass and dominated the shelf edge $(\sim 200 \mathrm{~m})$ and the tetractinellid Thenea sp. made up $42 \%$ of total sponge biomass. This species

Table 4 Table of species and sampling operations, by depth bin and gear type, used in calculation of species accumulation curves (Fig. 2)

\begin{tabular}{|c|c|c|c|c|c|c|c|c|}
\hline Depth Bin (m) & 200 & 400 & 1000 & 1500 & 2000 & 3000 & 4000 & Total \\
\hline Min depth (m) & 137 & 358 & 932 & 1321 & 1904 & 2467 & 3530 & 137 \\
\hline Max depth (m) & 283 & 483 & 1268 & 1863 & 2366 & 3465 & 4961 & 4961 \\
\hline Total number of species & 304 & 246 & 292 & 377 & 188 & 263 & 157 & 1267 \\
\hline Total number samples ${ }^{\mathrm{a}}$ & 16 & 16 & 31 & 67 & 58 & 79 & 22 & 289 \\
\hline ROV grab & 0 & 0 & 0 & 25 & 27 & 46 & 0 & 98 \\
\hline Beam trawl & 6 & 6 & 11 & 13 & 8 & 8 & 9 & 62 \\
\hline Dredge & 0 & 0 & 2 & 9 & 1 & 3 & 8 & 23 \\
\hline Sled & 0 & 0 & 0 & 3 & 0 & 1 & 5 & 9 \\
\hline Smith MacIntyre grab & 5 & 4 & 0 & 0 & 0 & 0 & 0 & 9 \\
\hline ICP/Multi-corer & 5 & 6 & 14 & 10 & 11 & 4 & 0 & 50 \\
\hline Piston corer & 0 & 0 & 3 & 0 & 4 & 0 & 0 & 7 \\
\hline Push core & 0 & 0 & 0 & 7 & 7 & 17 & 0 & 31 \\
\hline
\end{tabular}

${ }^{\text {aExcludes }} 15$ sampling operations that only retrieved taxa not included in Additional file 2 due to lack of taxonomic expertise 
dominated the slope and was the most widespread, being found at all depths between 400 and $3000 \mathrm{~m}$, with the highest concentration at $1000 \mathrm{~m}$. The genus Thenea has been found in aggregations in other deep sea sites around the world (e.g. off Norway and Greenland (Witte et al., 1997)), their long spicules perfect for living on deep sea mud (Schönberg, 2016).

Sponges from the Class Calcarea were only collected at the $200 \mathrm{~m}$ depth stratum and were apparently absent at the deeper sites. Calcarea have been thought to be depth-limited by the oceans' calcite compensation depth, but previous work has shown that this occurs deeper than $1000 \mathrm{~m}$ in the GAB (James, 2005) and so the apparent depth limitation of Calcarea may be due to factors other than spicule solubility. Identification of sponges in the Class Calcarea was facilitated by a specialised taxonomic workshop; nevertheless, electron microscopy will be needed to confirm some of these species identifications. Hexactinellid or glass sponges were the dominant class of sponges collected from the deeper sites. With a total of 49 taxa from at least seven families, only two glass sponges were identified to species level: Farrea cf. occa, known from deep waters in southern Australia, and Walteria flemmingi Schulze, 1886, which has been previously recorded from the Western Pacific region at depths between 350 and $5000 \mathrm{~m}$ (van Soest, 2008). No sponges of the class Homoscleromorpha were collected.

Of the total 225 sponge taxa, only eight were identified to known species, all of which have been previously recorded from Australia. Seven of the Calcarea were recognised as species new to science. Two Demospongiae warrant further investigation as possibly new genera. It is likely that there are several new species of Demospongiae, although further taxonomic work is needed to confirm this. In comparison, in a deep water collection in waters of Western Australia (100-1100 m) almost a third (28\% of 372 ) of the species were new to science (McEnnulty et al., 2011).

\section{Siphonophorae}

\section{H. MacIntosh}

Analysis of siphonophores, particularly deep sea varieties, is not normally a priority in biodiversity surveys due to the relative scarcity of both specimens and expertise. The group does merit inclusion here for a particular outcome of the combined surveys.

Benthic sampling at seven stations collected numerous small, rubbery, mushroom-shaped objects that were recognised as the rarely-seen Dendrogramma enigmatica Just, Kristensen \& Olesen, 2014 - an unusual invertebrate that had not been placed in any known animal phylum. First collected off southeast Australia in the 1980s, the species had not been found since, and the formalin preservation of the original specimens prevented genetic analysis.

The collection of fresh material allowed for detailed phylogenetic analysis of the species. Results show that Dendrogramma is a benthic siphonophore in the family Rhodaliidae, a poorly-understood group of benthic siphonophores related to the Portuguese Man-o-War (O'Hara et al., 2016). The mushroom shaped 'creatures' are in fact structures called bracts that are protective outgrowths from a siphonophore colony (Pugh, 1983). A small gas float and main colony were also collected and matched by DNA to Dendrogramma, but the appearance of the colonies and bracts in life remains a mystery.

\section{Antipatharia \\ T. Molodtsova}

Antipatharians, also known as black or thorny corals, are colonial anthozoans characterized by a chitinous skeletal axis covered to a varying degree with small spines. Approximately 250 species are presently known, from seven families. Black corals have a wide distribution, inhabiting marine waters from latitudes of $72^{\circ} \mathrm{N}$ to $68^{\circ} \mathrm{S}$ and depths from 2 to $3 \mathrm{~m}$ to $8600 \mathrm{~m}$ (Wagner et al., 2012; Molodtsova \& Opresko, 2017). In the deep sea black corals are most commonly associated with hard substrates, and are themselves important habitats for a range of associated fauna (Wagner et al., 2012). Nine species have been previously reported from the Great Australian Bight from 170 to 4750 m depth, with seven species listing the Great Australian Bight as the type locality (Brook, 1889; Opresko, 1998; Opresko, 1999; Opresko, 2003).

The combined GAB surveys collected 16 lots of black corals, representing nine species from four families. Of these, three species (Bathypathes tenuis Brook, 1889, Parantipathes helicosticha Opresko, 1999 and Leiopathes acanthophora Opresko, 1998) have been previously reported from the GAB or temperate Australia. Three genera (Stichopathes, Stauropathes and Heteropathes) are new records for the $\mathrm{GAB}$ and one species (Bathypathes sp.) is undescribed.

\section{Octocorallia}

\section{P. Alderslade}

Deep water Octocorallia are primarily represented by the orders Alcyonacea and Pennatulacea. The Alcyonacea comprise the bulk of the octocorals, which, depending on colony form, are generally referred to as soft corals and gorgonians (sea fans and sea whips), while members of the Pennatulacea are referred to as sea pens or rock pens. These two orders are cosmopolitan in distribution, occurring from pole to pole and from the intertidal to abyssal depths. They are well represented in 
Australian waters and jointly referred to below as 'octocorals'.

Octocorals were collected in nearly all operations targeting epifauna ( 50 beam trawls, 19 rock dredges and 10 benthic sleds) with a distinctive drop in abundance at the $400 \mathrm{~m}$ depth horizon. Catches of octocorals were generally small (mostly $<100 \mathrm{~g}$, with by far the largest containing $3 \mathrm{~kg}$ of Dendronephthya cf. waite Thomson \& Mackinnon, 1911), and the diversity within a catch was usually low. ROV collections were especially successful at retrieving whole, undamaged specimens that would otherwise be missed or destroyed by towed equipment. Collectively, however, the Alcyonacea were represented by 11 families, 33 genera and 49 species, and the Pennatulacea by seven families, nine genera and 25 species.

Many taxa were assigned an alpha-numeric code that CSIRO has been consistently applying to deep water octocoral collections in Australian waters (Alderslade et al., 2014; MarLIN, 2014). This is because the octocoral fauna is poorly described in the literature, and many identifications at species level could not be resolved to named species without extensive generic revision (Alderslade et al., 2014). Nevertheless, it was possible to distinguish three new genera and 28 new species of alcyonaceans, 12 new species of pennatulaceans, and an additional 17 new records for Australian waters including 13 new to the GAB. In all probability this reflects a paucity of collecting activities, not only in the GAB but in deep waters around the Australian continent as a whole.

\section{Actiniaria}

\section{A.L. Crowther, M. L. Mitchell}

Actiniaria are exclusively soft-bodied hexacorallian cnidarians known from shallow to deep regions of the ocean. In the deep sea, they occur in a range of environments, including abyssal depths (e.g. (Doumenc, 1975; White et al., 1999)), hydrothermal vents and cold seeps (e.g. (Lopez-Gonzalez et al., 2003; Rodríguez, 2012; Zelnio et al., 2009)), and whale falls (Daly \& Gusmão, 2007). Symbioses with gastropods and hermit crabs are also known from deep sea environments (Daly et al., 2004; Gusmão \& Daly, 2010; Rodríguez \& López-González, 2008). Actiniaria from deep sea regions of Australia are still relatively unknown; there have only been three species described from Australian representatives: Sicyonis erythrocephala (Pax, 1922), Stylobates birtlesi Crowther, Fautin \& Wallace, 2011 and Stylobates loisetteae Fautin, 1987.

The combined GAB surveys yielded 1109 actiniarian specimens, representing nine families, 21 genera, and 56 species. Nine distinct OTUs (50 specimens) could only be identified to the ordinal level. Of the identified actiniarians, one family, two genera, and 29 species represent new records for
Australia or the GAB. The increasing level of endemicity from family to species is not unexpected, with Rodríguez et al. (Rodríguez et al., 2007a) and Eash-Loucks and Fautin (Eash-Loucks \& Fautin, 2012) reporting the same trend in Antarctic and North West Pacific regions, respectively.

Hormathiidae are known to dominate the deep actiniarian fauna (Fautin \& Barber, 1999; Rodríguez et al., 2007b); the GAB results support this, with $72 \%$ of the identified specimens belonging to this family. Two species of hormathiids that had not been recorded in Australia previously were Paracalliactis cf. rosea Hand, 1976 and Monactis cf. vestita (Gravier, 1918). Paracalliactis cf. rosea represents the most widely distributed sea anemone collected, with a depth range of 1000-3000 m, while specimens of $M$. cf. vestita were most numerous. Other genera that were identified (Hormathia and Actinauge) have been previously collected in Australia and the GAB, and are currently in museum collections.

Actinostolidae are commonly represented in the deep sea (Fautin \& Hessler, 1989; Rodríguez et al., 2008), however, only five species of this family were identified. The genus Stomphia sp. is a new record for the GAB. Several Actiniaria, though found in far fewer numbers and smaller distribution, provide important new records. Likely to be a new species, Pacmanactis sp. is a new record for Australia; the only other described species in this genus is found on hydrothermal vents off Papua New Guinea (López-González et al., 2005). The Amphianthidae genera Amphianthus sp. and Stephanauge sp. are also well represented - neither genus has been recorded before from Australia.The actiniid Bolocera sp. is distinctive, due to the possession of deciduous tentacles, and is a new record for the Great Australian Bight. Five species of Actinernidae were collected during the cruises, including first known record for Isactinernus (a monotypic genus) outside of the tropical West Pacific. A new family record for the GAB is Andvakiidae, with the genus Epiphellia: this occurs from temperate Australia, but records are from shallow depths.

Research into fauna of the GAB is important, particularly for sea anemones. Fautin et al. (Fautin et al., 2013) showed that sea anemones exhibit the greatest species richness between latitudinal bands $30^{\circ}-40^{\circ} \mathrm{N}$ and $\mathrm{S}$, the band within which the GAB falls. Therefore, further taxonomic work will likely discover new species from this region. These surveys of the GAB provide important baseline knowledge of the actiniarian fauna, resulting in new distributional records, range extensions, and insight into the breadth of diversity.

\section{Scleractinia}

\section{N. Bax}

Cold deep water Scleractinian corals, commonly called stony corals, differ from their warmer water shallow 
counterparts in that they are azooxanthallate and most described species are formed from a single solitary polyp with a calcified skeleton (known as cup corals). The exception to this are the genera Solenosmilia which from large colonies and are a cosmopolitan fauna on Australian seamount and shelf locations, including the Great Australian Bight (Cairns, 2004).

Sixty-seven scleractinian species are endemic to the Australian region, 33 species are described from South Australia placing them within the GAB geographic vicinity (Cairns, 2004). The combined GAB surveys collected a total of 1783 scleractinian specimens, with 16 species from ten genera. Unlike many other faunal groups, there was a low degree of rarity, with only four species known from single specimens. Most species were well represented across sampling stations including the cosmopolitan species Deltocyathus magnificus Moseley, 1876, Solenosmilia variabilis Duncan, 1873 and Caryophyllia planilamellata Dennant, 1906.

Some species appear to be novel and require further analysis (potentially including molecular genetic research) to determine if they are new species, range extensions of known species or morphotypes unique to the GAB geographic region. Tentatively new species include Stephanocyathus sp. nov, Truncatoflabellum sp. nov (cf. T. vigintiforium?), and two Caryophyllia sp. nov. If these species are new to science, further work will be needed to document their morphology and determine if they are endemic to the GAB region. The genus Truncatoflabellum and the two species, Anthemiphyllia dentata, Caryophyllia deomedeae have never been recorded from South Australia, constituting range extensions herein.

\section{Annelida}

\section{R.S. Wilson, E. Kupriyanova, H. Maclntosh, A. Murray, $H$. Paxton}

The Annelida, or segmented worms, includes many of the groups important in marine, terrestrial and freshwater habitats: polychaetes, earthworms and leeches. In addition, recent discoveries based on molecular genetics (e.g. Andrade et al. (Andrade et al., 2015)) have established that the small former phyla Echiura, Sipuncula and Pogonophora must also be subsumed within the Annelida. One outcome of these recent advances is that the taxon 'Polychaeta' is now synonymous with Annelida. Despite this consensus from recent publications, Polychaeta continues to be widely used in the literature, so the traditional 'Polychaeta' are summarised as such in the tables to allow for comparison with other data sets.

In the marine environment, particularly in soft sediments, annelids are typically dominant, representing $40 \%$ or more of all individuals and species collected in typical benthic surveys (Hilbig \& Blake, 2006; Shields \& Blanco-Perez, 2013). However, most annelids are small and live on or below the sediment surface and are thus counted among the infauna in this study, although a few larger annelids are either found living on the sea floor and large enough to be retained in a beam trawl or similar gear, or are associated with corals, sponges and similar larger host invertebrates - these are considered epifaunal.

The annelid fauna from the combined surveys comprised 42 families represented by 179 species, of which over half (104) are likely to be undescribed. Among these, the dominant epifaunal annelid families were typical of similar depths anywhere in the world's oceans: Ampharetidae, Amphinomidae, Aphroditidae, Eunicidae, Onuphidae, Polynoidae and Serpulidae (Paterson et al., 2009). Serpulidae (worms whose calcareous tubes encrust corals, mollusc shells and other hard substrates) were especially diverse, with nine genera present. Other diverse epifaunal annelid families include Onuphidae (ten species) and Polynoidae (16 species). Sabellariidae were also present in epifaunal samples, represented by a species of a deep water genus not previously recorded from Australian waters (Gesaia sp. 1).

Annelids are vastly more numerous in infaunal samples where they are by far the dominant major taxon. Infaunal samples are more representative of the annelid fauna and included families typical of deep sea habitats in other parts of the world. Among the most species-rich were Cirratulidae (seven species), Paraonidae (five species), Sabellidae (seven species), Spionidae (16 species) and Syllidae (15 species). Other typical deep sea annelid families such as Ampharetidae, Amphinomidae, Fauveliopsidae, Goniadidae and Siboglinidae have never been collected in Australian waters at these depths.

Since this is the first systematic study of Annelida from depths to $5049 \mathrm{~m}$ in Australian waters, it is entirely to be expected that many apparently new species and new records have resulted. Further taxonomic studies by specialist taxonomists are expected to confirm these results and lead to formal description of many new species in coming years.

The annelid fauna discovered in the deep GAB is, at the family level, broadly representative of annelid faunas at similar depths elsewhere in the world. It is at the species level, however, that informative regional, bathymetric and other ecological distribution patterns are expected to emerge with further study.

\section{Bivalvia}

\section{H. Maclntosh}

Well known in shallow areas, bivalves also occur in the very deepest reaches of the oceans (Knudsen, 1970; Allen, 2008; Kamenev, 2015). They have adapted to the unique conditions of the deep sea and can constitute an important part of the benthos (Allen, 2008). These 
adaptations include chemosymbiosis to survive in vent or seep environments and multiple evolutions of carnivory, making up for the lack of phytoplankton (Poutiers \& Bernard, 1995; Barroso et al., 2016). As with other molluscan groups, shallow water bivalves are reasonably well studied in Australia, but the deep water fauna is poorly understood (Lamprell \& Whitehead, 1992; Beesley et al., 1998).

The combined GAB surveys yielded a large collection of bivalves, with 2103 total specimens representing 18 families and 43 species. These covered a wide range of bivalve groups including Protobranchia (Nucula, Tindaria), Pteriomorpha (Propeamussium, Hyalopecten), typical Heterodonta (Abra, Pratulum) and a variety of carnivorous 'septibranchs' (Poromya, Cuspidaria, Spinosipella). The overall diversity and abundance of bivalves were typical of similar deep water areas (McEnnulty et al., 2011; Allen, 2008), with the only notable differences being comparatively low numbers of protobranchs and no chemosynthetic species (e.g. Thyasiridae). Some notable finds include the families Tindariidae and Vesicomyidae, which have not been previously recorded in Australia. Additional specimens from southeast Australia have since been found in museum collections but have not previously made it into the published record. Another unusual find was a large aggregation of Limopsis 'sp. 3', with over 1000 individuals collected in a single trawl. These bivalves are specialist filter feeders in the deep sea (Oliver \& Allen, 1980), suggesting the local environment has a high suspended bacterial or sediment load.

No species could be initially determined as undescribed, but many merit further investigation. Despite the apparent lack of undescribed species, only 15 species were previously recorded from Australian waters, most likely due to the lack of deeper water (>2000 m) sampling in Australia. Several species found in the survey have been previously recorded in New Zealand, the central/eastern Pacific or are cosmopolitan (e.g. Abra profundorum (E. A. Smith, 1885)).

\section{Scaphopoda}

\section{F. Criscione}

Scaphopods are found at all latitudes and in depths from the littoral fringe to the abyssal (Scarabino \& Scarabino, 2011; Davies, 1987), where they inhabit all types of sediments from soft mud and silts to coarse mud and gravels. They are primarily micro-carnivorous generalists in their diets (Shimek, 1990), feeding on foraminiferans, bivalve spat, ostracods, diatoms, small gastropods, marine mites and invertebrate eggs. Many species, including several Australian species, are found over a wide depth range (e.g. Laevidentalium erectum (Sowerby, 1860) recorded from 11 to $2569 \mathrm{~m}$ ). Compared to other molluscan classes, scaphopods generally exhibit rather conserved morphology and ecology and do not exhibit any particular adaptation to deep sea environments. There are two major systematic groups in the Scaphopoda (the orders Dentaliida and Gadilida) with eleven families, of which eight are present in Australian deep waters (Beesley et al., 1998).

A total of 541 scaphopod specimens were collected, which were assigned to 11 species in five families. The family with the largest number of species retrieved (seven) was the Dentaliidae, of which four species were undescribed. One has been attributed to the genus Fissidentalium, another to the genus Graptacme and another is of uncertain generic placement. Two species of the Gadiliidae were collected, with two other families (Entalinidae and Laevidentaliidae) each represented by one known species.

All scaphopods collected are members of families already reported for Australian waters. Fissidentalium profundorum (E. A. Smith, 1894) and Rhomboxiphus tricarinatus (Boissevain, 1906) are here reported for the first time for the GAB. The latter record fills the gap in the known distribution of this entalinid species between the eastern and western Australian coasts.

\section{Cephalopoda}

\section{A.L. Reid, J.K. Finn}

Cephalopods within Australian waters are represented by approximately 230 species, currently grouped into $10 \mathrm{Or}-$ ders (Reid, 2016a). All are carnivorous, feeding at a range of trophic levels, and occupy all depths from the surface to the sea floor. Many species exhibit diel vertical migration, and may occupy different habitats and depths at different stages in their life cycles. They are both key predators and prey species in marine ecosystems.

A total of 23 cephalopod species in 13 families were collected during the combined surveys. Four species are undescribed. While many are well known and occur in other parts of Australia and elsewhere, a few species were new records for the GAB.

Of the species collected, the cuttlefish Sepiidae (Sepia cottoni Adam, 1979, S. cultrata Hoyle, 1885 and S. hedleyi Berry, 1918), and the Sepiolidae (Sepiolina sp. nov. and Austrorossia australis Berry, 1918) are Australian endemic taxa. All but $S$. cottoni were previously known to occur in the GAB (Reid, 2016a; Reid, 2016b). While Sepiolina and Austrorossia are benthic taxa, cuttlefishes (Sepia) are not true benthic cephalopods, but live close to the seafloor and use solid substrates for egg attachment. Another sepiolid, Heteroteuthis hawaiiensis (Berry, 1909) was collected; this is a new record for the GAB and Australia (Young et al., 2007). Unlike other sepiolids, this is a pelagic species, but evidence suggests they lay their eggs on the seafloor. The identification of 
this species was supported by molecular comparison of $\mathrm{CO} 1$ and $16 \mathrm{~S}$ gene sequences with $H$. hawaiiensis from the type locality (Hawaii). While Heteroteuthis was previously known from Australian waters, there has been some dispute regarding the identity of the previously reported heteroteuthids. This new collection has prompted a reassessment of representatives from other Australian locations.

The octopods included both incirrate and cirrate forms. Among the incirrate octopods 'Eledone' palari Lu \& Stranks, 1992 (Eledonidae) was collected at depths between 200 and $300 \mathrm{~m}$. Placement of this species within Eledone has been questioned (Norman et al., 2014) and material collected during this survey will aid in resolving the taxonomic assignment of this species. The specimens of Muusoctopus collected represent a new species; taxonomic study of existing museum material and specimens collected during this survey will allow formal description of this taxon. Two species, tentatively assigned to Octopus are undescribed. Specimens of the cirrate octopods, Opisthoteuthis persephone Berry, 1918 and O. pluto Berry, 1918 will also be valuable for future research. These species have been previously collected throughout southern Australia but neither species is well-known as their gelatinous bodies are easily damaged during collection.

Among the squids, perhaps the most notable find was a specimen of Joubiniteuthis portieri (Joubin, 1916) (Joubiniteuthidae). This species is rarely collected and only a few dozen specimens worldwide are known in museum collections (Young, 2009). This mesopelagic to bathypelagic squid has not previously been recorded from the GAB. Pyroteuthis margaritifera (Rüppell, 1844) (Pyroteuthidae) previously known from Australia (including the GAB) is generally thought to be a widely-distributed species, known to undertake diel vertical migration from about $250 \mathrm{~m}$ to shallower depths. Some morphological differences have been found among various populations of this species, which was originally described from the Mediterranean Sea. Whether all taxa that broadly conform to this species diagnosis are truly conspecific is yet to be determined, so pending future analyses of this possible species-complex it is listed here $P$. cf. margaritifera. The specimens collected during this survey could not be distinguished morphologically from $P$. margaritifera as currently defined (Young \& Mangold, 1996).

\section{Gastropoda}

\section{F. Criscione}

The composition of bathyal gastropod assemblages is profoundly influenced by the lack of photosynthetic life, which determines the absence of true herbivorous gastropods. Given the food resource available, the deep sea gastropod fauna is dominated by members of four major feeding guilds: scavengers, deposit-feeders, predators and parasites (Allen, 1983).

Scavengers are represented by a number of families in the subclass Vetigastropoda including the Osteopeltidae (whale and fish bones, (Marshall, 1987)), Lepetellidae (tubes of polychaete worms, empty egg-cases of sharks and rays (Powell, 1979)), and Pseudococculinidae (sunken plant remains (Hickman, 1983)). In the subclass Caenogastropoda, some bathyal species of Buccinidae (e.g. Enigmaticolus, (Fraussen, 2008)) and Nassariidae (Dekker \& Dekkers, 2009) are scavengers. Deep sea scavengers in the subclass Cocculiniformia are limpets of the Cocculinidae (Haszprunar, 1987; Marshall, 1986) (herbivorous) and the Bathysciadiidae (Haszprunar, 1988) (feeding on sunken cephalopod beaks). Many of the deposit feeders are vetigastropods, such as species of the families Seguenziidae and Calliotropidae (Kano, 2008), but in this category there are also some caenogastropod families, such as the Rissoidae (Ponder, 1984). Deep sea predators belong to a wide range of phylogenetically diverse caenogastropod groups, such as many conoidean families (e.g. Raphitomidae, Pseudomelatomidae, Drilliidae, and Borsonidae) (Bouchet et al., 2011), which paralyse their polychaete prey by injecting venom through modified arrow-like radular teeth. Other predators include the families Muricidae, Fasciolariidae, Volutidae, Belomitridae and Naticidae, which bore a hole through the shell of their molluscan prey, using their radula and an acid secretion (Carriker, 1998) and the Cassidae, which also use a combination of radula rasping and acid secretion to access the flesh of echinoids (Beu et al., 2008). Among the parasites, the Eulimidae (Caenogastropoda) are always associated with echinoderm hosts, from which they extract the body fluids through a muscular proboscis (Bouchet \& And, 1986). Other deep sea ectoparasite species are present in the caenogastropod Epitoniidae (having cnidarian hosts) (Bouchet \& And, 1986) and the heterobranch Pyramidellidae, with primarily polychaete hosts (Peñas \& Rolán, 2010).

A total of 1468 gastropod specimens were collected from the GAB surveys, assigned to 110 species in 42 families. Fifty-four species are new to science. The family with the largest number of species retrieved was the Raphitomidae (one described, 17 undescribed species), followed by the Muricidae (six described, three undescribed), the Fasciolariidae (three described, two undescribed), the Epitoniidae (one described, seven undescribed), the Arminidae (four undescribed) the Velutinidae (four undescribed) and the Ranellidae (three described). All remaining families included three species or less. All gastropods collected were members of families already recorded for Australia and (excluding the Belomitridae) for the GAB and all including species typical of deep sea environments. Of the 37 described 
species, three (Hadroconus diadematus Marshall, 1988, Halystes chimaera B. A. Marshall, 1988 and Spergo aithorris Sysoev \& Bouchet, 2001) represent the first record for Australian waters, while nine species have not previously been reported from the GAB.

\section{Asteroidea \\ C. Mah}

The diversity of shallow-water Asteroidea in the Australian region has been historically well-studied and is regarded as one of the richest in the world (Rowe \& Gates, 1995; Clark, 1921; Clark, 1938; Livingstone, 1932; Clark \& Rowe, 1971). In contrast, the asteroid deep sea fauna in the Australian region is very poorly characterised. Deeper water faunas from the continental shelf are surveyed in part by H.L. Clark (Clark, 1916) with early members reported by Sladen (Sladen, 1889). A far more extensive literature on the South Pacific deep sea Asteroidea has been published on the New Zealand fauna (Clark \& McKnight, 2000; Clark \& McKnight, 2001; McKnight, 2006), which includes many species also present in Australia and adjacent regions.

Asteroids are significant ecological members of shallow marine communities where they occupy significant ecological roles and can strongly affect community structure (Paine, 1966; Paine, 1969). Although the role of deep sea asteroids is not as well understood as those in shallow-water, it seems likely that they occupy a similar role; some deep sea species have been observed feeding on octocorals and have been recorded in abundance on abyssal plains.

The combined GAB surveys included 89 species from 40 genera in 18 families, with 17 species determined to be new to science. All families represented are known from lower bathyal to abyssal depths and include several well-known deep sea or cold-water members such as the Pterasteridae and the Zoroasteridae, amongst the most diverse of known deep sea groups.

Apart from some shallower water species (Luidia prionota Fisher, 1913, Pseudophidiaster rhysus H.L. Clark, 1916 and Smilasterias spp.), the majority of taxa collected represent new occurrence records for Australia. Although many occurrence records had been recorded from nearby localities such as New Zealand, there were many that represented significant range extensions - the genus Calyptraster has previously only been known from the tropical Atlantic and southern Indian Ocean. Several species had not been recorded since the HMS Challenger surveyed nearby areas in the nineteenth Century.

Although poorly understood, some ecological information can be inferred from the taxa sampled. For example, members of the Astropectinidae, Pseudarchasteridae and especially the Porcellanasteridae occur on soft unconsolidated sediments (Mah \& Blake, 2012). Many of the recovered species were members of groups that have been observed on unconsolidated sediment or soft-bottoms. Brisingids are suspension feeders, variably occurring on soft and hard substrates (Mah, 2016). Gut contents from species of Calyptraster and Hymenaster are new observations; these included gastropods and bivalves from muddy settings. Several asteroids including Styracaster caroli Ludwig, 1907, Dytaster sp., Plutonaster spp., and Pillsburiaster spp. were observed with their disks gorged with mud. In addition to providing us with baseline information on echinoderm diversity for the region, observations such as these have provided valuable insights into substratum, habitat and ecology of the asteroid fauna of the deep GAB.

\section{Ophiuroidea}

\section{T. O'Hara}

Brittle-stars are abundant in deep water benthic habitats, where they feed on detritus, food falls or plankton. They are exclusively marine, but occur from the coast to the deepest oceanic trenches and from the equator to polar regions, inhabiting both rocky and soft-sediment substrata, and living epizoically on arborescent cnidarians and sponges (Stohr et al., 2012). Their ubiquitous distribution makes them a model group for the study of marine biogeography (O'Hara et al., 2011; Woolley et al., 2016). There are approximately 2100 described and several hundred undescribed morpho-species (Stohr et al., 2012). However, genetic studies indicate that traditional morphological species delimitation is problematic, and that many morpho-species are complexes of non-interbreeding cryptic species. The extant radiation of ophiuroids dates back to the Permian Period, 270 mya and there have been major radiations of ophiuroids in shallow water tropical habitats (e.g. Ophiotrichidae) and at upper bathyal depths (e.g. Ophiacanthidae, Ophiopyrgidae) (O'Hara et al., 2017).

The ophiuroid fauna of the GAB has been sampled previously as fisheries bycatch or incidentally from scientific expeditions, with most samples collected from less than $1000 \mathrm{~m}$ depths. The combined 2013-2017 surveys yielded a large collection of ophiuroid species across a range of depths (199-4961 m), comprising 64 species in 23 families and all six orders. Two species were very abundant, Ophiomusa lymani (Wyville Thomson, 1873) (1000-2800 m) and Ophiocten australis Baker, 1979 (1500-4300 m - here recognised as distinct from Ophiocten hastatum Lyman, 1848). The most speciose genus was Ophiomusa (formerly confused with Ophiomusium), however, the GAB Ophiomusa species are not necessarily closely related as the genus is ancient (90 mya) and requires taxonomic revision.

There are numerous undescribed species in the collection. Although some of these species have been found elsewhere in temperate Australia (e.g. Ophiomitrella sp. 
MoV 2779), others appear to be new (e.g. Ophiura sp. MoV 7067, Ophioscolex sp.). Many lower bathyal and abyssal species (2000-4600 m) have been found outside Australia. Whether these represent complexes of species is typically unknown, although for one abyssal species (Amphiophiura bullata (Thomson, 1878)) there is only shallow genetic divergence over vast geographical distances (GAB, Northern Pacific, Southern Atlantic).

\section{Echinoidea}

\section{A. Miskelly}

Of the 300 or so echinoid species known to occur in Australia, many are widespread across the Indo-Pacific oceans, particularly those that live in sub-tropical and tropical areas. The southern Australian States show a greater number of endemic species, though these generally prefer shallower waters. Deep water regular echinoid species are dominated by Echinothuriids and Phormosomatids, rather delicate urchins that 'deflate' when they are brought to the surface, often losing spines and pedicellariae in the process, which can hinder identification to species level. Other minor families that are found in deep water include the Saleniidae (e.g. Salenocidaris hastigera (A. Agassiz, 1879), a small widespread species that also occurs north to the Indo-Malay Archipelago and around New Zealand) and the Pedinidae, in which several deep water species are known from Australia and across to New Zealand. Irregular sea urchins such as sand dollars (Clypeasteroids) and heart urchins (Spatangoids) are poorly represented.

The combined GAB surveys collected 932 echinoid specimens, with 19 species from 12 families. Only a single species, the sand dollar Clypeaster sp. nov. 1 was determined to be undescribed. It was especially abundant at some sampling locations and is known from other specimens housed in Australian museum collections. Several 'species' could not be confidently identified due to being juvenile, (Caenopedina sp.), or being damaged; the heart urchin Argopatagus vitreus A. Agassiz, 1879 was collected only as tiny fragments until the 2017 ROV sampling recovered three intact specimens of this exceedingly fragile species.

Significant discoveries include the first Australian records for Tromikosoma and Sperosoma. Species showing range extensions include Goniocidaris sibogae Mortensen, 1928 (previously known only from New South Wales, Victoria and Tasmania), Lovenia camarota H.L. Clark, 1917 (previously known from North Western Australia), Aceste ovata A. Agassiz \& H.L. Clark, 1907 (known from only a few specimens in Australia) and Pseudolovenia cf. hirsuta A. Agassiz \& H.L. Clark, 1907 (previously known only from Hawaii and Japan). A number of small sea urchins, probably belonging to the Echinothuriidae that were unable to be identified to species level due to their small size, could represent additional undescribed species.

\section{Holothuroidea \\ P.M. O'Loughlin, E. Whitfield}

Holothuroidea are amongst the dominant fauna at bathyal and abyssal depths, where they are predominantly soft sediment deposit feeders (Hansen, 1975). There are extensive collections of Holothuroidea from the eastern and western continental slopes of Australia (McEnnulty et al., 2011), but few have been recovered to date from the deep GAB.

The combined GAB surveys collected 1707 holothurian specimens, comprising 32 species in 22 genera from 12 families. Fourteen species were recognized and described, and of these 12 were known previously from Australia. There are 17 undescribed species. The myriotrochid Prototrochus roniae O'Loughlin \& Macintosh, 2015 was collected in the 2013 surveying and described in 2015.

This collection is remarkable both for the high proportion of what appear to be unknown species (53\%), and for the absence of species known from the eastern and western Australian slopes (such as a number of Laetmogone and Peniagone species). In addition, many of the species collected were single specimens, and further sampling may be required to reach a more comprehensive representation of the taxa present. Over half the specimens collected were the small gelatinous swimming sea cucumber Enypniastes eximia Théel, 1882, known from abyssal environments worldwide.

Unfortunately, many of the holothuroid specimens were extensively damaged during collecting. External morphological form was frequently not evident, and identification was primarily through ossicle form and size. In many cases there was not adequate material for describing new taxa. For example, three new species of the order Molpadida were represented (in genera Molpadia and Paracaudina). Each of these species was only represented by single specimens, and in two cases the specimens are extensively damaged. One species of the order Synaptida (in the genus Protankyra) was represented, with only one very damaged specimen.

Of the 14 described species, 12 have been recorded previously from the Australian slope: the deimatids Deima validum Théel, 1879 and Oneirophanta mutabilis Théel, 1879; the holothuriid Holothuria (Panningothuria) austrinabassa O'Loughlin, 2007 (in O'Loughlin et al. 2007); the laetmogonid Laetmogone maculata (Théel, 1879); the mesothuriids Mesothuria regularia Heding, 1940 and Zygothuria lactea (Théel, 1886); the myriotrochid Prototrochus roniae O'Loughlin \& Macintosh, 2015; the pelagothuriid Enypniastes eximia Théel, 1882; and the synallactids Bathyplotes natans (Sars, 1868), Molpadiodemas involutus (Sluiter, 
1901), Pseudostichopus hyalegerus (Sluiter, 1901) and Pseudostichopus mollis Théel, 1886.

The two known species not recorded previously for the Australian slope are the elpidiid Peniagone azorica von Marenzeller, 1893 and the psychropotid Psychropotes longicauda Théel, 1882. Peniagone azorica is thought to be cosmopolitan but numerous morphological variations are reported (Hansen, 1975). Psychropotes longicauda has also been thought to be cosmopolitan but recent genetic studies (Gubili et al., 2016) have revealed probable cryptic species diversity. We anticipate that genetic studies will reveal cryptic species diversity for numbers of these supposedly cosmopolitan species.

Of the 17 undescribed new species, six belonging to the typically bathyal order Elasipodida were represented (in genera Benthodytes, Ellipinion, Kolga, Peniagone and Psychropotes). Four new species of the order Aspidochirotida are represented (in genera Mesothuria, Pseudostichopus and Synallactes). Three new species of the order Molpadida are represented (in genera Molpadia and Paracaudina). There are nine lots of an undescribed species of Mesothuria that is widespread on the Australian slope.

\section{Cirripedia}

\section{A.M. Hosie}

Deep water barnacles have been relatively well documented in waters adjacent to Australia such as Antarctica (Newman \& Ross, 1971), the Malay Archipelago (Hoek, 1883; Hoek, 1907; Hoek, 1913; Calman, 1919; Chan, 2009), New Caledonia (Buckeridge, 1994; Buckeridge, 1997; Jones, 2000; Chan et al., 2014) and New Zealand (Foster, 1978; Foster, 1980; Foster, 1981). The deep water barnacle fauna of Australia has been summarised by Jones (Jones, 2000; Jones, 2012; Jones, 1991) and Jones et al. (Jones et al., 1990), but there are few recent taxonomic accounts that describe Australia's deep sea barnacles (e.g. (Jones, 1992; Zevina, 1988; Zevina, 1981)) and the results of many expeditions remain unpublished.

The present material reveals that the deep waters of the GAB have a higher diversity than what was previously known and represents some of the deepest records of barnacles in Australian waters. In total 678 barnacle specimens were examined, resulting in the identification of 32 species in five families. As is expected in deep water, the stalked barnacle family Scalpellidae was the most diverse family, represented by 15 species. Five species were not conclusively assigned to a named species and four have been given tentative identifications (Gibbosaverruca cf. nitida (Hoek, 1883), Metaverruca cf. recta (Aurivillius, 1898), Neoscalpellum cf. schizoplacinum Newman \& Ross, 1971, Trianguloscalpellum cf. uniarticulatum (Nilsson-Cantell, 1921)). The uncertainty of these identifications is a reflection of the paucity of knowledge on Australia's deep sea barnacles. Members of the genera Gymnoscalpellum, Meroscalpellum and Neoscalpellum are particularly problematic as they are characterised by an extreme reduction of the capitular plates during ontogeny, making identification of individual specimens very difficult. A compounding issue is that barnacles of these genera have often been described in isolation and from a single or a few specimens, giving little information on intraspecific variation.

The species collected showed a high degree of novelty with one undescribed species, Metaverruca sp. nov. 1, and five, seven, and eight species recorded for the first time from the waters of Australia, temperate Australia and the GAB, respectively. Of the species that are reported in Australia for the first time, G. cf. nitida and Planoscalpellum distinctum (Hoek, 1883) have been reported to be widely distributed in the tropical Indo-West Pacific (Foster \& Buckeridge, 1994; Young, 2002) and T. cf. uniarticulatum has only been recorded from Sino-Japanese waters (Liu \& Ren, 2007). In contrast Meroscalpellum bifurcatum (Zevina, 1973) has been reported in the southern Atlantic and Indian Oceans (Foster \& Buckeridge, 1995) and Neoscalpellum schizoplacinum Newman \& Ross, 1971 is known from the Southeast Pacific Basin in the Southern Ocean (Newman \& Ross, 1971).

Jones et al. (Jones et al., 1990), in their catalogue of Australian barnacles, listed 19 species being present deeper than $200 \mathrm{~m}$ within the EEZ of the southern coast of Australia, of these only six were recollected during this survey (Arcoscalpellum inum Zevina, 1981, Gibbosaverruca navicula (Hoek, 1913), Glyptelasma hamatum (Calman, 1919), Metaverruca cf. recta, Trianguloscalpellum regium and Verum candidum (Hoek, 1907)). Thus, the number of known species has been increased to 38 . Only A. inum is endemic to Australia, and is in fact only known from the GAB. Overall, the barnacle fauna represented in this collection showed a mix of northern and southern species and are normally wide ranging. Two species, Amigdoscalpellum costellatum (Withers, 1935) and Trianguloscalpellum cf. regium have been reported in all oceans. Other species, such as Arcoscalpellum truncatum (Hoek, 1883), Eutomolasma maclaughlinae Jones, 2000 and Verum australicum (Hoek, 1883), have previously been found in northern Australia and are typically found in deep tropical waters of the Indo-West Pacific.

\section{Isopoda}

\section{K. Merrin}

The Isopoda are an important component of shelf, slope and deep sea ecosystems. One group, the Asellota, are the species-rich sub-order predominately found in these habitats (Brandt et al., 2004; Brandt et al., 2007; Raupach 
et al., 2009), although knowledge of this group in Australian waters remains limited (Poore et al., 1994).

The combined GAB surveys collected a rich and diverse sample of isopods, with 599 specimens consisting of 21 families, 45 genera and 61 species. The most frequently collected species was the serolid Brucerolis victoriensis Storey \& Poore, 2009, which made up 78\% of the overall specimens collected. All the isopod families collected were previously recorded from bathyal and abyssal depths.

Unsurprisingly, the most diverse suborder was the Asellota, with 39 species from 10 families. This figure concurs with previous studies, showing that asellotes are the most dominant isopod group in the deep sea (Brandt et al., 2004; Brandt et al., 2007; Raupach et al., 2009). Overall, $82 \%$ of the isopod species collected are undescribed, and four species represent likely new genera. Such a high level of taxonomic novelty is not surprising, as previous Australian deep water surveys have invariably uncovered high levels of undescribed isopod taxa (Poore et al., 1994; Poore et al., 2014).

Of the described species, only five have been previously recorded from the GAB. Conversely, four families (Macrostylidae, Katianiridae, Nannoniscidae and Thambematidae) are new records for Australian waters and are important additions to the deep water fauna of Australia.

\section{Decapoda, Stomatopoda and Lophogastrida S.T. Ahyong, C.a. Farrelly, a.W. McCallum}

Decapod and lophogastridan crustaceans are common in deep water, and stomatopods less common (Wilson \& Ahyong, 2015). Most decapods and stomatopods are benthic or epibenthic, although some, like the lophogastridans, are pelagic or bentho-pelagic. Decapoda and Stomatopoda are most diverse in the shallow tropics, but are nevertheless common in temperate shelf and slope waters.

The combined surveys of decapods, stomatopods and lophogastridans collected 2835 specimens, dominated by decapods. The single species of stomatopod collected, Anchisquilloides mcneilli (Stephenson, 1953), is already known from southern Australia and the two lophogastridans are cosmopolitan at abyssal depths.

The decapods comprised 36 families, 75 genera and 114 species, spanning groups typical of the upper shelf to slope waters and deeper. Twenty species (18\%) are new to science and $32(30 \%)$ represent new records for the GAB. The numerically dominant decapods at bathyal depths surveyed $(>1000 \mathrm{~m})$ were parapagurid hermit crabs. Other decapod families are more typical of the upper shelf such as the hermit crabs of the families Diogenidae and Paguridae, and brachyuran crabs of the families Dromiidae, Inachidae, Leucosiidae, and Majidae.
Within the range of the shallower stations $(\sim 150$ $400 \mathrm{~m}$ ), the dominant decapods are spider crabs (Epialtidae, Inachidae, Majidae). These general patterns are consistent with those observed for the deep water decapods off Western Australia (McEnnulty et al., 2011; Poore et al., 2008) and the family and generic level composition is similar to that observed in deep water habitats around New Zealand (Ahyong, 2008; Rowden et al., 2010). The several specimens of Cymonomus delli Griffin \& Brown, 1975 collected represent a significant rediscovery of the species, previously known only from the holotype collected off Sydney in 1972 (Ahyong \& Ng, 2009).

All of the undescribed species belong to genera already recorded from Australian waters, although their nearest congeners may not be Australian as in the new species of squat lobsters, Munida, Munidopsis and Gastroptychus, whose nearest relatives occur farther afield in the Indo-West Pacific (Baba et al., 1905). The three new Australian records represent significant range extensions: Heterogenys microphthalma (Smith, 1885) - cosmopolitan, nearest previous record from New Zealand; Parapagurus furici Lemaitre, 1999 - previously known from tropical Indo-West Pacific including New Caledonia and the Lord Howe Rise; and Munidopsis arietina Alcock \& Anderson, 1894 - previously known from the Bay of Bengal and Taiwan.

\section{Pycnogonida \\ D. Staples}

Pycnogonids are an exclusively marine group of arthropods found worldwide from the intertidal to the deep sea. Almost 1400 species are described, about 200 of which are from Australian waters. The combined GAB surveys collected 142 specimens, representing 14 species in seven genera and four families. Five of the 14 species are new to science.

This collection is highly significant in that it is the most extensive collection of deep sea pycnogonids to date from this poorly sampled and little understood region. The collection is dominated by specimens belonging to the deep sea genus Colossendeis. This genus includes species that are the 'giants' of the pycnogonid fauna with leg spans commonly in the $125-500 \mathrm{~mm}$ range but where specimens with leg spans of up to about $700 \mathrm{~mm}$ have been recorded. These large specimens can only survive in the deep sea and are well adapted to the stable environment that it provides. In common with other long-legged pycnogonids, specimens in this genus are reliant on slow-moving, deep sea currents; not only in search of food but for the distribution of their gene pool. By treading water rapidly, they can lift themselves into the water column and then be carried over vast distances with little further effort. The seven species of 
Colossendeis identified here are widely distributed and probably cosmopolitan.

Included in this collection are forms that belong to the 'Colossendeis macerrima' Wilson, 1881 complex. Rarely has any group of pycnogonids been subjected to such rigorous taxonomic scrutiny and yet their status remains unresolved. The ongoing taxonomic confusion has largely extended from the incomplete description of the C. macerrima holotype, but based on specimens in this collection, its status can be clarified. The status of the other species herein referred to as C. cf. minor is not resolved. Molecular analyses suggest that more than one species is represented and further analysis based on morphological characters is required. Those specimens will form part of a detailed analysis of the species complex based on a wider range of southern Australian material.

This collection has several noteworthy taxonomic and biogeographic records. Five new species were found belonging to the genera Colossendeis, Callipallene, Parapallene, Meridionale and Chonothea. The genus Chonothea was previously known from Japan and is a new record for Australian waters.

Bathypallenopsis antipoda (Clark, 1972) represents a new record for Australia and this is only the second record of the species. Colossendeis spicula Child, 1994 represents the second record of the species in Australian waters and is only known (outside Australia) from Oregon, USA. Colossendeis cucurbita Cole, 1909 is also a new record in Australian waters.

Lastly, the abundance of specimens belonging to the genus Colossendeis in this collection has enabled comparison with the original type material for the genus and the status of two species has been clarified. These species are perhaps the most commonly recorded representatives of the genus Colossendeis in deep sea collections outside of the polar regions.

\section{Discussion}

Collectively, the surveys were highly successful, resulting in a diverse collection of invertebrates. After taxonomic analysis, the collection was determined to contain over 66,000 specimens, representing 1267 species. A total of 40 major invertebrate groups were present from eleven phyla, with a total of 386 families and 710 genera.

The overall diversity and abundance of benthic invertebrates were typical of temperate deep sea communities, as noted in taxonomic summaries presented in this paper. Apart from the new taxa noted, the families and genera present were all known to occur in the deep sea, and most species had been previously recorded in Australia, or more broadly. Nonetheless, the material includes the deepest biological samples from Australian waters and has provided an excellent opportunity to study Australia's deep sea fauna, particularly in the poorly-sampled southern coast region. The collection contains many new records for Australia, several new genera and has provided high-quality tissue samples for genetic analysis. These surveys will provide the means for considerable further ecological, biogeographical and systematic research.

Species accumulation curves (Fig. 2) show little plateauing with number of samples, suggesting the true number of species in the deep GAB is much higher. Although obscured by higher sampling effort at the 1500$3000 \mathrm{~m}$ bathomes, results suggest a decreasing number of species with depth, a trend corroborated by an accompanying study of GAB megafaunal patterns (Williams et al., 2018a). In addition, while using gear type as a proxy for habitat may suggest a much higher species richness in soft sediment habitats, this is more likely the result of the larger size and sampling area of the Beam Trawl, which has not been controlled for here. The total amount of sampling effort on hard substrates was much lower, due to the selective nature of ROV sampling and limited number of Rock Dredge and Benthic Sled operations. Ongoing analysis of photographic transects at soft sediment, volcanic seamounts and rocky outcrops will help elucidate the differences in community composition between substrate types (Williams et al., 2018c).

The abundance of invertebrates was also typical of deep sea habitats; species were patchily distributed and often rare. Of the total species, 398 (31\%) were known from only single specimens, with 579 (46\%) known from one or two specimens. This high degree of apparent rarity is likely to be due to relatively low sampling effort compared with well-studied regions elsewhere, and has also been seen in exploratory deep water sampling elsewhere in Australia and overseas (Poore et al., 2014).

The number of undescribed species (401, 32\% of total) was unsurprising, given the depths sampled and general lack of exploration in the region. The result closely matches the proportion of undescribed species in other recent Australian deep sea surveys (e.g. 36\% on the western Australian shelf by Poore et al. (Poore et al., 2014)). Some taxonomic groups were represented by a high proportion of undescribed species (e.g. 80\% Isopoda, 61\% Annelida, 49\% Gastropoda, 53\% Holothuroidea), whereas for others the figure was comparatively low ( 19\% Asteroidea, 18\% Decapoda). This is likely due to a combination of these latter groups being larger and more easily collected, occurring more widely in the deep sea and having more taxonomic attention paid to describing new species. It is indicative of the level of taxonomic novelty encountered by sampling for the first time at such depths, that in addition to new species, the material also included nine new genera. Phyla where species identification is difficult, especially Porifera (sponges), are likely to contain additional new species once 
further morphological and molecular taxonomic work is complete.

Despite the number of undescribed species, almost one-third of the species collected (382 species, 30\%) were previously recorded from Australia, many having been encountered in other exploratory surveys of the west and south coasts (e.g. (McEnnulty et al., 2011; Poore et al., 1994)). Of these, only 207 were known previously from the $\mathrm{GAB}$, highlighting the lack of sampling in the region. Wide distributions are common in deep sea animals, but studies on regional and global scales are still too scarce to generalise from, and this is an ongoing area of research with much effort directed to understanding the relationship between sampling effort, distribution patterns and diversity in deep sea environments ((Danovaro, 2009; de Forges et al., 2000; Grassle \& Maciolek, 1992; Gray et al., 1997; Schüller \& Ebbe, 2007) and references cited therein). Several species collected, including several of the most abundant (e.g. Ophiomusa lymani), have cosmopolitan distributions in the deep sea. New records include previously described species (e.g. Enixotrophon veronicae, Munidopsis arietina) and even families never reported from Australian waters (e.g. Vesicomyidae, Katianiridae).

\section{Conclusions}

The deep GAB has remained a blind spot in our knowledge of Australia's deep sea diversity. Concern over possible human impacts has provided the impetus to finally rectify this. The 2013-2017 GAB surveys have produced a high quality biological data set and a collection of over 66,000 specimens, encompassing some of the deepest systematically sampled environments in Australian waters. While being broadly similar in makeup to deep sea environments elsewhere in Australia and worldwide, there is a great deal of novelty in the fauna, with a quarter remaining to be described. The morphological, genetic and ecological data associated with these collections will serve as the basis for comparative taxonomic and biogeographic research for years to come.

\section{Additional files}

Additional file 1: Photographs of invertebrate fauna collected during 2013-2017 surveys of the GAB. Each photo caption includes the CAAB number (unique taxonomic identifier), survey name (e.g. IN2015_C01), station and accession number (e.g. 126-187) and species name. (PDF $44048 \mathrm{~kb}$ )

Additional file 2: List of invertebrate species collected during 20132017 surveys of the GAB. Each record lists the total number of specimens collected, number of stations collected, minimum and maximum depth collected (in meters), whether the species is undescribed and if the species has been previously recorded from Australia, the GAB and temperate Australia (signified by "Y"). (XLSX $111 \mathrm{~kb}$ )

\section{Abbreviations}

AM: Australian Museum, Sydney; CSIRO: Commonwealth Scientific and Industrial Research Organisation; GAB: Great Australian Bight; NMV: Museums Victoria, Melbourne; SAMA: South Australian Museum, Adelaide; SARDI: South Australian Research and Development Institute; WAM: Western Australian Museum, Perth

\section{Acknowledgments}

The authors wish to acknowledge funding support for two research programs that supported collection and preparation of the data presented here:

The Great Australian Bight Research Program (GABRP) is a collaboration between $\mathrm{BP}, \mathrm{CSIRO}$, the South Australian Research and Development Institute (SARDI), the University of Adelaide, and Flinders University. The Program aims to provide a whole-of-system understanding of the environmental, economic and social values of the region; providing an information source for all to use.

The Great Australian Bight Deepwater Marine Program (GABDMP) is a CSIRO led research program sponsored by Chevron Australia, with data generated to be made publicly available.

The authors would also like to thank the many staff from CSIRO, the Marine National Facility, and other participating agencies who helped in various ways to acquire the biological samples. Many sea-going and land-based contributions have been required to successfully collect, process and document the fauna reported here. Post-processing and analysis has involved a great deal of collaboration by all participating institutions, including the efforts of legal, finance and collections managers to ensure contracting, analysis and handling of material has gone smoothly and efficiently.

\section{Funding}

Funding was provided by the two project bodies:

The Great Australian Bight Research Program (GABRP), a collaboration between BP, CSIRO, the South Australian Research and Development Institute (SARDI), the University of Adelaide, and Flinders University.

The Great Australian Bight Deepwater Marine Program (GABDMP), a CSIRO led research program sponsored by Chevron Australia.

\section{Availability of data and materials}

Images and data generated from this study are available in the form of Additional files 1 and 2. These provide a complete record of species found in the deep GAB and notes on novelty and occurrence. Specimens are lodged at participating Australian museums (Table 3) and are available for study.

\section{Authors' contributions}

AW and JET secured project funding, designed sampling regimes and led surveys. FA compiled and distributed data. HM coordinated taxonomic analysis. HM, FA, AW and JET edited the manuscript. PA, STA, FC, ALC, NB, CF, JF, LG, KGH, AMH, EK, HM, CM, AWM, KM, TM, AM, MLM, AM, TOH, MOL, $H P, A L R, S J S, D S, G W S, E W$ and RSW provided taxonomic analysis and wrote sections on specific faunal groups. HM produced the Tables. FA and KGH produced figures and Additional file 1. All authors read and approved the final manuscript.

\section{Ethics approval}

Collections were conducted with permits for accessing biological resources in Commonwealth waters (AU-COM2013-186, AU-COM2015-284 \& AUCOM2017-340), sampling in Commonwealth Marine Reserves (005-ARRR130301-01, CMR-15-000344 \& CMR-17-000449), Australian Fisheries Management Authority fishing permits $(1,002,443,1,002,838,1,003,307 \& 1,003,308)$. In accordance with animal ethics guidelines (CSIRO AEC permits 16/2012$13,19 / 2014-15$ \& 2017-02), specimens were anaesthetised with isotonic Magnesium Chloride before preservation, whenever necessary.

\section{Consent for publication}

All authors consent to publication.

\section{Competing interests}

The authors declare that they have no competing interests. 


\section{Publisher's Note}

Springer Nature remains neutral with regard to jurisdictional claims in published maps and institutional affiliations.

\section{Author details}

${ }^{1}$ Museums Victoria, Melbourne, Australia. ${ }^{2} \mathrm{CSIRO}$ Oceans and Atmosphere, Hobart, Australia. ${ }^{3}$ SARDI Aquatic Sciences, Adelaide, Australia. ${ }^{4}$ Australian Museum Research Institute, Sydney, Australia. Institute of Marine and Antarctic Studies, Hobart, Australia. ${ }^{6}$ South Australian Museum, Adelaide, Australia. ${ }^{7}$ Western Australia Museum, Perth, Australia. ${ }^{8}$ National Museum of Natural History, Smithsonian Institution, Washington, DC, USA. ${ }^{9}$ Independent Researcher, Sydney, Australia. ${ }^{10}$ P.P. Shirshov Institute of Oceanology RAS, Moscow, Russia.

\section{Received: 12 December 2017 Accepted: 11 October 2018} Published online: 03 November 2018

\section{References}

Ahyong ST. Deepwater crabs from seamounts and chemosynthetic habitats off eastern New Zealand (Crustacea: Decapoda: Brachyura). Zootaxa. 2008;1708: $1-72$.

Ahyong ST. Polychelid lobsters (Decapoda: Polychelida: Polychelidae) collected by the CIDARIS expeditions off Central Queensland, with a summary of Australian and New Zealand distributions. Mem Queensl Museum. 2012;56:1-7.

Ahyong ST, Ng PKL. The Cymonomidae of the Philippines (Crustacea: Decapoda: Brachyura), with descriptions of four new species. Raffles Bull Zool. 2009;20: 233-46.

Alderslade P, Althaus F, McEnnulty FR, Gowlett-Holmes K, Williams A. Australia's deep-water octocoral fauna: historical account and checklist, distributions and regional affinities of recent collections. Zootaxa. 2014;3796:435-52.

Allen JA. The ecology of deep-sea molluscs. In: Russell-Hunter WD, editor. The Mollusca, Vol. 6, Ecology. Orlando: Academic Press; 1983. p. 29-75.

Allen JA. Bivalvia of the deep Atlantic. Malacologia. 2008;50:57-173.

Andrade SCS, Novo M, Kawauchi GY, Worsaae K, Pleijel F, Giribet G, et al. Articulating "Archiannelids": Phylogenomics and annelid relationships, with emphasis on meiofaunal taxa. Mol Biol Evol. 2015;32:2860-75.

Baba K, Macpherson E, Poore GCB, Ahyong ST, Bermudez A, Cabezas P, et al. Catalogue of squat lobsters of the world (Crustacea: Decapoda: Anomura families Chirostylidae, Galatheidae and Kiwaidae). Zootaxa. 2008;1905:1-220.

Barroso CX, Salani S, Rabay SG, Matthews-Cascon H. Septibranchia (Mollusca: Bivalvia) from the north and northeast coasts of Brazil. Mar Biodivers Rec. 2016;9:1-14.

Beesley PL, Ross GJB, Wells A. Mollusca: the southern synthesis. Melbourne: CSIRO Publishing; 1998

Beu AG, Héros V, Cowie RH, Bouchet P. Recent deep-water Cassidae of the world: a revision of Galeodea, Oocorys, Sconsia, Echinophoria and related taxa, with new genera and species (Mollusca, Gastropoda). Mémoires du Muséum Natl d'Histoire Nat. 2008;169:269-387.

Bouchet, P. and AW. Revision of the Northeast Atlantic bathyal and abyssal Aclididae, Eulimidae, Epitoniidae (Mollusca, Gastropoda). Boll Malacol Suppl 1986;2:297-576

Bouchet P, Kantor YI, Sysoev A, Puillandre N. A new operational classification of the Conoidea (Gastropoda). J Molluscan Stud. 2011;77:273-308.

Brandt A, Brökeland W, Brix S, Malyutina MV. Diversity of Antarctic deep-sea isopoda (Crustacea, malacostraca) - a comparison with shelf data. Deep Sea Res Part II Top Stud Oceanogr. 2004;51:1753-69.

Brandt A, Gooday AJ, Brandão SN, Brix S, Brökeland W, Cedhagen T, et al. First insights into the biodiversity and biogeography of the Southern Ocean deep sea. Nature. 2007:447:307-11.

Brook G. Report on the Antipatharia collected by HMS Challenger during the years 1873-1876. Rep Sci res Chall 1873-76. Zool. 1889;32:1-222.

Buckeridge JS. Cirripedia Thoracica: Verrucomorpha of New Caledonia, Indonesia, Wallis and Futuna Islands. Mem du Museum Natl d'Histoire Nat. 1994;161:87-125.

Buckeridge JS. Cirripedia Thoracica: new ranges and species of Verrucomorpha from the Indian and Southwest Pacific oceans. Mem du Museum Natl d'Histoire Nat. 1997;176:125-49.

Cairns SD. The Azooxanthellate Scleractinia (Coelenterata: Anthozoa) of Australia. Rec Aust Museum. 2004;56:259-329.

Calman WT. On the barnacles of the genus Megalasma from deep-sea telegraphcables. Ann Mag Nat Hist. 1919;9:361-74.
Carriker MR. Predatory gastropod traces: a comparison of verified shallow-water and presumed deep-sea boreholes. Am Malacol Bull. 1998;14:121-31.

Chan BKK. Shallow water and Deep-Sea barnacles (Crustacea: Cirripedia: Thoracica) collected during the Philippine Panglao 2005 expedition, with description of two new species. Raffles Bull Zool. 2009;20:47-82.

Chan BKK, Corbari L, Moreno PA, Jones DS. Two new deep-sea stalked barnacles, Arcoscalpellum epeeum sp. nov. and Gymnoscalpellum indopacificum sp. nov., from the Coral Sea, with descriptions of the penis in Gymnoscalpellum dwarf males. Zootaxa. 2014;3866:261-76.

Clark AM, Rowe FWE. Monograph of shallow-water indo-West Pacific echinoderms. 1971

Clark HES, McKnight DG. The marine Fauna of New Zealand: Echinodermata: Asteroidea (sea-stars) 1. Order Paxillosida, Notomyotida. NIWA Biodivers Mem. 2000;116:1-196.

Clark HES, McKnight DG. The marine Fauna of New Zealand: Echinodermata: Asteroidea (sea-stars) 2. Order Valvatida NIWA Biodivers Mem. 2001;117: $1-270$.

Clark HL. Report on the Sea-Lilies, Starfishes, Brittle-Stars and Sea-Urchins obtained by the F.IS. " Endeavour " on the coasts of Queensland, New South Wales, Tasmania, Victoria, South Australia, and Western Australia. Biol Results Fish Exp carried by FIS "Endeavour," 1909-14. 1916:4:3-123.

Clark HL. The echinoderm fauna of Torres Strait: its composition and its origin. Carnegie Inst Washingt. 1921;214:1-223.

Clark HL. Echinoderms from Australia, an account of collections made in 1929 and 1932. Mem Museum Comp Zool. 1938:55:1-596.

Conlan KE, Currie DR, Dittmann S, Sorokin SJ, Hendrycks E. Macrofaunal patterns in and around du couedic and bonney submarine canyons, South Australia. PLoS One. 2015;10:1-27.

Currie DR, Sorokin SJ. A preliminary assessment of the deepwater benthic communities of the Great Australian Bight Marine Park: Report to the South Australian Department of Environment and Natural Resources and the Commonwealth Department of Sustainability, Environment, Water, Population and Communities. Adelaide: SARDI Aquatic Sciences, Publication No. F2011/000526-1; 2011.

Daly M, Ardelean A, Cha HR, Campbell AC, Fautin DG. A new species, Adamsia obvolva (Cnidaria: Anthozoa: Actiniaria), from the Gulf of Mexico, and a discussion of the taxonomy of carcinoecium-forming sea anemones. Bull Mar Sci. 2004;74:385-99.

Daly M, Gusmão L. The first sea anemone (Cnidaria: Anthozoa: Actiniaria) from a whale fall. J Nat Hist. 2007:41:1-11.

Danovaro R. Methods for the study of deep-sea sediments, their functioning and biodiversity. Boca Raton: CRC Press; 2009.

Davies GJ. Aspects of the biology and ecology of deep-sea Scaphopoda (Mollusca). Edinburgh: Heriot-Watt University; 1987.

de Forges BR, Koslow JA, Poore GCB. Diversity and endemism of the benthic seamount fauna in the southwest Pacific. Nature. 2000;405:944-7.

Dekker H, Dekkers AM. A new species, Nassarius kooli n. sp. (Gastropoda: Nassariidae), from deep water in the Philippines and Japan. Misc Malacol. 2009:3:117-20

Domingos C, Lage A, Muricy G. Overview of the biodiversity and distribution of the class Homoscleromorpha in the tropical Western Atlantic. J Mar Biol Assoc United Kingdom. 2016;96:379-89.

Doumenc DA. Actinies bathyales et abyssales de l'océan Atlantique nord familles des Hormathiidae (genres Paracalliactis et Phelliactis) et des Actinostolidae (genres Actinoscyphia et Sicyonis). Bull du Muséum Natl d'Histoire Nat. 1975;197:157-204.

Eash-Loucks WE, Fautin DG. Taxonomy and distribution of sea anemones (cnidaria: Actiniaria and corallimorpharia) from deep water of the northeastern pacific. Zootaxa. 2012;3375:1-80.

Fautin DG, Barber BR. Maractis rimicarivora, a new genus and species of sea anemone (Cnidaria: Anthozoa: Actiniaria: Actinostolidae) from an Atlantic hydrothermal vent. Proc Biol Soc Washingt. 1999;112:624-31.

Fautin DG, Hessler RR. Marianactis bythios, a new genus and species of actinostolid sea anemone (Coelenterata: Actiniaria) from the Mariana vents. Proc Biol Soc Washingt. 1989;102:815-25.

Fautin DG, Malarky L, Soberón J. Latitudinal diversity of sea anemones (cnidaria: Actiniaria). Biol Bull. 2013;224:89-98.

Forest J. Compte rendu et remarques générales (texte bilingue) / Report and general comments (bilingual text). Résultats des campagnes MUSORSTOM, 1. Mémoires ORSTOM. 1981;91:9-50.

Foster BA. The marine fauna of New Zealand: barnacles (Cirripedia: Thoracica). New Zeal Oceanogr Inst Mem. 1978;69:1-160. 
Foster BA. Further records and classification of scalpellid barnacles (Cirripedia, Thoracica) from New Zealand. New Zeal J Zool. 1980;7:523-31.

Foster BA. Cirripedes from ocean ridges north of New Zealand. New Zeal J Zool. 1981;8:349-67.

Foster BA, Buckeridge JS. Barnacles (Cirripedia, Thoracica) of seas off Reunion Island and the east indies. Bull du Muséum Natl d'Histoire Nat. 1994;16:345-82.

Foster BA, Buckeridge JS. Barnacles (Cirripedia: Thoracica) of seas off the straits of Gibraltar. Bull du Muséum Natl d'Histoire Nat. 1995;17:163-92.

Fraussen K. Enigmaticolus, a new genus of deep water buccinids (Gastropoda: Buccinidae), with description of a new species from Madagascar. Gloria Maris. 2008:46:74-82.

Grassle JF, Maciolek NJ. Deep-Sea species richness: regional and local diversity estimates from quantitative bottom samples. Am Nat. 1992;139:313-41.

Gray JS, Poore GCB, Ugland KI, Wilson RS, Olsgard F, Johannessen O. Coastal and deep-sea benthic diversities compared. Mar Ecol Prog Ser. 1997;159:97-103.

Gubili C, Ross E, Billett DSM, Yool A, Tsairidis C, Ruhl HA, et al. Species diversity in the cryptic abyssal holothurian Psychropotes longicauda (Echinodermata). Deep Res Part II Top Stud Oceanogr. 2016;In Press.

Gusmão LC, Daly M. Evolution of sea anemones (Cnidaria: Actiniaria: Hormathiidae) symbiotic with hermit crabs. Mol Phylogenet Evol. 2010;56:868-77.

Hansen B. Systematics and biology of the deep-sea holothurians. Part I Elasipoda Galathea Rep. 1975;13:1-262.

Haszprunar G. Anatomy and affinities of cocculinid limpets (Mollusca, Archaeogastropoda). Zool Scr. 1987;16:305-24.

Haszprunar G. Anatomy and relationships of the bone-feeding limpets, Cocculinella minutissima (smith) and Osteopelta mirabilis Marshall (archaeogastropoda). J Molluscan Stud. 1988:54:1-20.

Hickman CS. Radular patterns, systematics, diversity, and ecology of deep-sea limpets. Veliger. 1983:26:73-92.

Hilbig B, Blake JA. Deep-sea polychaete communities in the Northeast Pacific Ocean off the gulf of the Farallones. California Bull Mar Sci. 2006;78:243-69.

Hoek PPC. Report on the Cirripedia collected by H.M.S. Challenger during the years 1873-76. Rep Sci Results Voyag HMS Chall 1873-76. 1883;8:1-169.

Hoek PPC. The Cirripedia of the Siboga Expedition. A. Cirripedia pedunculata. In: Siboga Expedition Monograph 31. Leyden: E.J Brill; 1907. p. 1-127.

Hoek PPC. The Cirripedia of the Siboga Expedition. B. Cirripedia sessilia. In: Siboga Expedition Monograph 31b. Leyden: E.J Brill; 1913. p. 129-275.

Hooper JNA, Hall KA, Ekins M, Erpenbeck D, Wörheide G, Jolley-Rogers G. Managing and sharing the escalating number of sponge "unknowns": the spongemaps project. Integr Comp Biol. 2013;53:473-81.

James NP. Where has all the aragonite gone? Mineralogy of Holocene neritic cool-water carbonates, Southern Australia. J Sediment Res. 2005;75:454-63.

Jones DS. A history of the discovery and description of Australian barnacles (Cirripedia: Thoracica), including a bibliography of reference works. Arch Nat Hist. 1991;18:149-78.

Jones DS. Scalpellid barnacles (Cirripedia: Thoracica) from the northeastern and central eastern Australian continental shelf and slope. Mem Queensl Museum. 1992;32:145-78

Jones DS. Crustacea Cirripedia Thoracica: Chionelasmatoidea and Pachylasmatoidea (Balanomorpha) of New Caledonia, Vanuatu and Wallis and Futuna Islands, with a review of all currently assigned taxa. Mem du Museum Natl d'Histoire Nat. 2000;184:141-283.

Jones DS. Australian barnacles (Cirripedia: Thoracica), distributions and biogeographical affinities. Integr Comp Biol. 2012;52:366-87.

Jones DS, Anderson JT, Anderson DT. Checklist of the Australian Cirripedia. Tech Reports Aust Museum. 1990;3:1-38.

Kamenev GM. Composition and distribution of bivalves of the abyssal plain adjacent to the Kuril-Kamchatka trench (Pacific Ocean). Deep Sea Res Part II Top Stud Oceanogr. 2015;111:188-97.

Kano Y. Vetigastropod phylogeny and a new concept of Seguenzioidea: independent evolution of copulatory organs in the deep-sea habitats. Zool Scr. 2008:37:1-21.

Knudsen J. The systematics and biology of abyssal and hadal Bivalvia. Galathea Rep. 1970;11:1-241.

Koslow JA, Gowlett-Holmes K, Lowry JK, O'Hara TD, Poore GCB, Williams A. Seamount benthic macrofauna off southern Tasmania: community structure and impacts of trawling. Mar Ecol Prog Ser. 2001;213:111-25.

Lamprell KL, Whitehead T. Bivalves of Australia, volume 1. Bathurst: Crawford House Press; 1992.

Last PR, Lyne VD, Williams A, Davies CR, Butler AJ, Yearsley GK. A hierarchical framework for classifying seabed biodiversity with application to planning and managing Australia's marine biological resources. Biol Conserv. 2010;143: $1675-86$.

Lewis M. CSIRO-SEBS (seamount, Epibenthic sampler), a new epibenthic sled for sampling seamounts and other rough terrain. Deep Sea Res Part I Oceanogr Res Pap. 1999;46:1101-7.

Lewis M. Sherman the epibenthic sled for rough terrain. (CSIRO Marine and Atmospheric Research paper; 029. 2009.

Lewis M. The CSIRO $4 \mathrm{~m}$ Beam Trawl (CSIRO Marine and Atmospheric Research Paper 033). Hobart; 2010.

Liu R, Ren X. Crustacea, Cirripedia, Thoracica. In: Fauna Sinica, Invertebrata. Beijing: Science Press; 2007. p. 633.

Livingstone AA. Asteroidea. Great Barrier Reef expedition, 1928-29. Sci Rep. 1932; 4:241-65.

Lopez-Gonzalez PJ, Rodríguez E, Gili JM, Segonzac M. New records on sea anemones (Anthozoa: Actiniaria) from hydrothermal vents and cold seeps. Zool Verh. 2003;345:215-43.

López-González PJ, Rodríguez E, Segonzac M. A new species of sea anemone (Cnidaria: Anthozoa: Actiniaria) from Manus Basin hydrothermal vents, Southwestern Pacific. Mar Biol Res. 2005;1:326-37.

Mah CL. A new species of Brisingenes from the Hawaii undersea military munitions assessment area with an overview of Hawaiian brisingid in situ video observations and functional morphology of subambulacral spines (Forcipulatacea; Asteroidea). Deep Res Part II Top Stud Oceanogr. 2016;128:43-52.

Mah CL, Blake DB. Global diversity and phylogeny of the Asteroidea (Echinodermata). PLoS One. 2012;7(4):e35.

MarLIN. Deep-sea octocorals, first compilation of regional and distributional records of deep-water corals. 2014.

Marshall BA. Recent and tertiary Cocculinidae and Pseudococculinidae (Mollusca: Gastropoda) from New Zealand and New South Wales. New Zeal J Zool. 1986:12:505-46.

Marshall BA. Osteopeltidae (Mollusca: Gastropoda): a new family of limpets associated with whale bone in the deep sea. J Molluscan Stud. 1987:53:121.

McEnnulty FR, Gowlett-Holmes K, Williams A, Althaus F, Fromont J, Poore GCB, et al. The Deepwater megabenthic invertebrates on the western continental margin of Australia (100-1500m depths): composition, distribution and novelty. Rec West Aust Museum. 2011:80:1-191.

McKnight DG. The marine fauna of New Zealand: Echinodermata: Asteroidea (sea-stars). 3. Orders Velatida, Spinulosida, Forcipulatida, Brisingida with addenda to Paxillosida, Valvatida. NIWA Biodivers Mem. 2006;120:1-187.

MNF. RV Southern Surveyor Voyage Report: Great Australian Bight Science Plan Benthic, Pelagic and Petroleum Geochemistry Themes. 2013. Available at http://www.mnf.csiro.au/ /media/Files/Voyage-plans-and-summaries/ Southern-Surveyor/Noyage\%20plans20plans-summaries/2013/ VOYAGE\%20SUMMARY\%20t02-13.ashx. Accessed 17 Oct 2018

MNF. RV Investigator Voyage summary: IN2015_C01 - GAB deep water geological and benthic ecology program. 2015a. Available at: http://mnf.csiro.au/ /media/ Files/Noyage-plans-and-summaries/Investigator/Noyage\%20Plans\% 20summaries/2015/IN2015_C01-Voyage\%20Summary\%20FINAL\%2020160122. ashx. Accessed 17 Oct 2018.

MNF. RV Investigator Voyage summary: IN2015_C02. 2015b. http://mnf.csiro.au/ Voyages/Investigator-schedules/Plans-and-summaries/2015.aspx. Accessed 17 Oct 2018.

Molodtsova TN, Opresko DM. Black corals (Anthozoa: Antipatharia) of the clarionClipperton fracture zone. Mar Biodivers. 2017:47:349-65.

Morrow C, Cárdenas P. Proposal for a revised classification of the Demospongiae (Porifera). Front Zool. 2015;12:7.

Newman WA, Ross A. Antarctic cirripedia. Antarct Res Ser. 1971;14:1-257.

Norman MD, Finn JK, Hochberg FG. Family Octopodidae. In: Cephalopods of the World - An annotated and illustrated catalogue of cephalopod species known to date. No. 4, Vol. 3. Octopods and Vampire Squids. FAO Species Catalogue for Fishery Purposes. Rome: FAO; 2014. p. 36-215.

O'Hara TD, Hugall AF, Maclntosh H, Naughton KM, Williams A, Moussalli A. Dendrogramma is a siphonophore. Curr Biol. 2016;26:R457-8.

O'Hara TD, Hugall AF, Thuy B, Stohr S, Martynov AV. Restructuring higher taxonomy using broad-scale phylogenomics: the living Ophiuroidea. Mol Phylogenet Evol. 2017;107:415-30.

O'Hara TD, Rowden AA, Bax NJ. A southern hemisphere bathyal fauna is distributed in latitudinal bands. Curr Biol. 2011;21:226-30.

Oliver PG, Allen JA. The functional and adaptative morphology of deep-sea species of the family Limopsidae (Bivalvia: Arcoida) from the Atlantic. Philos Trans R Soc London. 1980;291:45-125. 
Opresko DM. New species of Leiopathes (Cnidaria: Anthozoa: Antipatharia) from southern Australia. Rec South Aust Museum. 1998;31:99-111.

Opresko DM. New species of Antipathes and Parantipathes (Cnidaria: Anthozoa: Antipatharia) from coastal waters of South Australia and Tasmania. Rec South Aust Museum. 1999;32:143-54.

Opresko DM. Revision of the Antipatharia (Cnidaria: Anthozoa). Part 3. Cladopathidae. Zool Med Leiden. 2003;77:495-536.

Paine RT. Food web complexity and species diversity. Am Nat. 1966;100:65-75.

Paine RT. The Pisaster-Tegula Interaction : Prey Patches, Predator Food Preference, and Intertidal Community Structure. Ecology. 1969;50:950-61.

Paterson GLJ, Glover AG, Barrio Froján CRS, Whitaker A, Budaeva N, Chimonides J, et al. A census of abyssal polychaetes. Deep Res Part II Top Stud Oceanogr. 2009;56:1739-46.

Peñas A, Rolán E. Deep water Pyramidelloidea of the tropical South Pacific: Turbonilla and related genera. Mémoires du Muséum Natl d'Histoire Nat. 2010;200:1-436.

Ponder WF. A review of the Genera of the Rissoidae (Mollusca: Mesogastropoda: Rissoacea). Rec Aust Museum. 1984;Suppl. 4:1-221.

Poore GCB, Avery L, Błażewicz-Paszkowycz M, Browne J, Bruce NL, Gerken S, et al. Invertebrate diversity of the unexplored marine western margin of Australia: taxonomy and implications for global biodiversity. Mar Biodivers. 2014.

Poore GCB, Just J, Cohen BF. Composition and diversity of Crustacea isopoda of the southeastern Australian continental slope. Deep Res Part I. 1994:41:677-93.

Poore GCB, McCallum AW, Taylor J. Decapod Crustacea of the continental margin of southwestern and Central Western Australia: preliminary identifications of 524 species from FRV southern surveyor voyage SS10-2005. Museum Victoria Sci Reports. 2008;11:1-108.

Poutiers J-M, Bernard FR. Carnivorous bivalve molluscs (Anomalodesmata) from the tropical western Pacific Ocean, with a proposed classification and a catalogue of recent species. Campagnes MUSORSTOM. 1995;14:107-87.

Powell AW. New Zealand Mollusca: marine, land and freshwater shells. Auckland: Collins; 1979.

Pugh PR. Benthic Siphonophores: a review of the family Rhodaliidae (Siphonophora, Physonectae). Philos Trans R Soc B Biol Sci. 1983;301:165-300

Rapp HT, Janussen D, Tendal OS. Calcareous sponges from abyssal and bathyal depths in the Weddell Sea, Antarctica. Deep Res Part II Top Stud Oceanogr. 2011;58:58-67.

Raupach MJ, Mayer C, Malyutina M, Wägele J-W. Multiple origins of deep-sea Asellota (Crustacea: isopoda) from shallow waters revealed by molecular data. Proc R Soc London B Biol Sci. 2009:276:799-808.

Rees AJJ, Yearsley GK, Gowlett-Holmes K, Pogonoski J. Codes for Australian aquatic biota (on-line version). CSIRO Marine and Atmospheric Research. 1999; http://www.cmar.csiro.au/caab/. Accessed 29 Mar 2017.

Reid AL. Cephalopods of Australia and sub-Antarctic territories: CSIRO Publishing. Edinburgh: Heriot-Watt University; $2016 \mathrm{a}$.

Reid AL. Post-mortem drift in Australian cuttlefish sepions: its effect on the interpretation of species ranges. Molluscan Res. 2016b;36:9-21.

Rodríguez E. First endomyarian sea anemone (Cnidaria, Actiniaria) putatively from chemosynthetic environments: a new deep-sea genus and species from the North Pacific. Mar Biol Res. 2012;8:791-801.

Rodríguez E, Castorani CN, Daly M. Morphological phylogeny of the family Actinostolidae (Anthozoa:Actiniaria) with description of a new genus and species of hydrothermal vent sea anemone redefining the family Actinoscyphiidae. Invertebr Syst. 2008;22:439-52.

Rodríguez E, Daly M, Fautin DG. Actiniaria. In: the phylum Cnidaria: a review of phylogenetic patterns and diversity 300 years after Linnaeus. Zootaxa. 2007b; 1668:127-82.

Rodríguez E, López-González PJ. The gastropod-symbiotic sea anemone genus Isosicyonis Carlgren, 1927 (Actiniaria: Actiniidae): a new species from the Weddell Sea (Antarctica) that clarifies the taxonomic position of the genus. Sci Mar. 2008;72:73-86.

Rodríguez E, López-González PJ, Gili JM. Biogeography of Antarctic Sea anemones (Anthozoa, Actiniaria): what do they tell us about the origin of the Antarctic benthic fauna? Deep Res Part II Top Stud Oceanogr. 2007a;54:1876-904

Rogers PJ, Ward TM, van Ruth PD, Williams A, Bruce BD, Connell SD, et al. Physical processes, biodiversity and ecology of the Great Australian Bight region : A Lite. Australia: CSIRO; 2013.

Rowden AA, Leduc D, Clark MR, Bowden DA. Habitat differences in deep-sea megafaunal communities off New Zealand: implications for vulnerability to anthropogenic disturbance and management. Front Mar Sci. 2016:1-19.
Rowden AA, Schnabel KE, Schlacher TA, Macpherson E, Ahyong ST, Richer De Forges B. Squat lobster assemblages on seamounts differ from some, but not all, deep-sea habitats of comparable depth. Mar Ecol. 2010;31:63-83.

Rowe FWE, Gates J. Echinodermata; Zoological Catalogue of Australia no. 33. 1995.

Sayers J, Bernardel G, Parums R. Geological framework of the central great Australian bight and adjacent areas. Geoscience Australia Record 2003/12. 2003.

Scarabino V, Scarabino F. Ten new bathyal and abyssal species of Scaphopoda from the Atlantic Ocean. Nautilus (Philadelphia). 2011;125:127-36.

Schönberg CHL. Happy relationships between marine sponges and sediments a review and some observations from Australia. J Mar Biol Assoc United Kingdom. 2016;96:493-514.

Schüller M, Ebbe B. Global distributional patterns of selected deep-sea Polychaeta (Annelida) from the Southern Ocean. Deep Sea Res Part II Top Stud Oceanogr. 2007:54:1737-51.

Sherlock M, Marouchos A, Williams A. An Instrumented Corer Platform for Seabed Sampling and Water Column Characterisation. In: Proceedings of the OCEANS-14 MTS/IEEE Conference, Taipei. IEEE; 2014. p. 1-6.

Shields MA, Blanco-Perez R. Polychaete abundance, biomass and diversity patterns at the mid-Atlantic ridge, North Atlantic Ocean. Deep Res Part II Top Stud Oceanogr. 2013;98:315-25.

Shimek RL. Diet and habitat utilization in a northeastern Pacific Ocean scaphopod assemblage. Am Malacol Bull. 1990;7:147-69.

Sladen WP. Report on the Asteroidea. Rep Sci Results Voyag HMS Chall 1873-76. Zoology. 1889;30:1-893.

Stohr S, O'Hara TD, Thuy B. Global diversity of brittle stars (Echinodermata: Ophiuroidea). PLoS One. 2012;7.

Tanner JE, Althaus F, Sorokin SJ, Williams A. Benthic biogeographic patterns in the southern Australian deep sea: do historical museum records accord with recent systematic, but spatially limited, survey data? Ecol Evol. 2018;(in press).

The Great Australian Bight Deepwater Marine Program. 2017. http://www.csiro. au/en/Research/EF/Areas/Oil-gas-and-fuels/Offshore-oil-and-gas/GABDeepwater. Accessed 8 Dec 2017.

The Great Australian Bight Research Program. 2017. http://www.misa.net.au/GAB. Accessed 8 Dec 2017

van Soest RWM. Walteria flemmingi Schulze, 1886. In: Van Soest, R.W.M; BouryEsnault, N.; Hooper, J.N.A.; Rützler, K.; de Voogd, N.J.; Alvarez de Glasby, B; Hajdu, E.; Pisera, A.B.; Manconi, R.; Schoenberg, C.; Klautau, M.; Picton, B.; Kelly, M.; Vacelet, J.; Dohrmann, M.; Díaz, M.-C.; Cárdenas, P.; Ca. 2008. http://www. marinespecies.org/porifera/porifera.php? $p=$ taxdetails\&id=171884. Accessed 5 Apr 2017.

van Soest RWM. Demospongiae. Glover, A.G., Higgs, N., Horton, T. World Register of Deep-Sea species. 2009. http://www.marinespecies.org/deepsea/aphia. php?p=taxdetails\&id=164811. Accessed 30 Mar 2017.

Van Soest RWM, Boury-Esnault N, Vacelet J, Dohrmann M, Erpenbeck D, De Voogd NJ, et al. Global Diversity of Sponges (Porifera). PLoS ONE. 2012;7(4): e35105.

Wagner D, Luck DG, Toonen RJ. The Biology and Ecology of Black Corals (Cnidaria: Anthozoa: Hexacorallia: Antipatharia). 1st edition. Elsevier Ltd. 2012.

White TR, Wakefield PAK, Fautin DG. Abyssal Sea anemones (Cnidaria: Actiniaria) of the Northeast Pacific symbiotic with molluscs: Anthosactis nomados, a new species, and Monactis vestita (Gravier, 1918). Proc Biol Soc Washingt. 1999;112:637-51.

Williams A, Althaus F, Clark MR, Gowlett-Holmes K. Composition and distribution of deep-sea benthic invertebrate megafauna on the Lord Howe rise and Norfolk ridge, Southwest Pacific Ocean. Deep Res Part II Top Stud Oceanogr. 2011:58:948-58.

Williams A, Althaus F, Maclntosh H, Loo M, Gowlett-Holmes K, Tanner JE, et al. Characterising the invertebrate megafaunal assemblages of a deep-sea (200$3000 \mathrm{~m}$ ) frontier region for oil and gas exploration: the Great Australian Bight, Australia. Deep Sea Res Part II Top Stud Oceanogr. 2018a;in press.

Williams A, Althaus F, Osterhage D, Trefry C, Ross A. Seafloor (benthic) habitats in the deep Great Australian Bight - Project 4 Benthic biota of volcanic seamounts, seeps and canyons of the GAB. Sub-project 4.3.2.1.C Habitat Classification. Final Report. 2018c.

Williams A, Althaus F, Pogonoski J, Osterhage D, Gomon M, Graham K, et al. Composition, diversity and biogeographic affinities of the deep-sea (200$3000 \mathrm{~m}$ ) fish assemblage in the Great Australian Bight, Australia. Deep Res Part II Top Stud Oceanogr. 2018b. 
Wilson GDF, Ahyong ST. Lifestyles of the species-rich and fabulous: the deep-sea crustaceans. In: Watling L, Thiel M, editors. The Natural History of the Crustacea, Vol. II: Lifestyles and Feeding Biology: Oxford University Press; 2015. p. 279-98.

Witte U, Brattegard T, Graf G, Springer B. Particle capture and deposition by deep-sea sponges from the Norwegian-Greenland Sea. Mar Ecol Prog Ser. 1997;154:241-52.

Woolley SNC, Tittensor DP, Dunstan PK, Guillera-Arroita G, Lahoz-Monfort JJ, Wintle BA, et al. Deep-sea diversity patterns are shaped by energy availability. Nature. 2016.

Young PS. Revision of the Verrucidae (Crustacea, Cirripedia) from the Atlantic Ocean studied by Abel Gruvel (Travailleur and talisman scientific expeditions). Zoosystema. 2002;24:771-97.

Young RE. Joubiniteuthidae Naef, 1922. 2009. http://tolweb.org/Joubiniteuthis_ portieri/19450. Accessed 1 Nov 2017.

Young RE, Mangold KM. Pyroteuthis margaritifera (Ruppell, 1844) version 1 January 1996. 1996. http://tolweb.org/Pyroteuthis_margaritifera/19758.

Young RE, Vecchione M, Roper CFE. Heteroteuthis hawaiiensis berry 1909. 2007. http://tolweb.org/Heteroteuthis_hawaiiensis/20055. Accessed 20 July 2011.

Zelnio KA, Rodríguez E, Daly M. Hexacorals (Anthozoa: Actiniaria, Zoanthidea) from hydrothermal vents in the South-Western Pacific. Mar Biol Res. 2009;5: $547-71$.

Zevina GB. Deep-sea Cirripedia of the Australian and New Zealand waters. Tr Instituta Okeanol Akad Nauk SSSR. 1981;105:76-93.

Zevina GB. Deep-sea Verrucomorpha (Cirripedia, Thoracia) of the Pacific. 2. The South Pacific. Zool Zhurnal. 1988;67:31-40.

Ready to submit your research? Choose BMC and benefit from:

- fast, convenient online submission

- thorough peer review by experienced researchers in your field

- rapid publication on acceptance

- support for research data, including large and complex data types

- gold Open Access which fosters wider collaboration and increased citations

- maximum visibility for your research: over $100 \mathrm{M}$ website views per year

At $\mathrm{BMC}$, research is always in progress.

Learn more biomedcentral.com/submissions 